University of Rhode Island

DigitalCommons@URI

Open Access Master's Theses

1989

\title{
The Formulation of Premium-Style Ice Milk, Low in Lactose, Sugar and Fat
}

Thanos Alagialis

University of Rhode Island

Follow this and additional works at: https://digitalcommons.uri.edu/theses

\section{Recommended Citation}

Alagialis, Thanos, "The Formulation of Premium-Style Ice Milk, Low in Lactose, Sugar and Fat" (1989). Open Access Master's Theses. Paper 995.

https://digitalcommons.uri.edu/theses/995

This Thesis is brought to you for free and open access by DigitalCommons@URI. It has been accepted for inclusion in Open Access Master's Theses by an authorized administrator of DigitalCommons@URI. For more information, please contact digitalcommons-group@uri.edu. 
THE FORMULATION OF PREMIUM-8TYLE ICE MILK,

LOW IN LACTOSE, SUGAR AND FAT

BY

THANOS ALAGIALIS

A THESIS SUBMITTED IN PARTIAL FULFILIMENT OF THE REQUIREMENTS FOR THE DEGREE OF

MASTER OF SCIENCE

IN

FOOD SCIENCE AND NOTRITION

ONIVERSITY OF RHODE ISLAND

1989 
MASTER OF SCIENCE THESIS

OF

ATHANASSIOS ALAGIALIS

Approved:

Thesis Committee:

Major Professor:

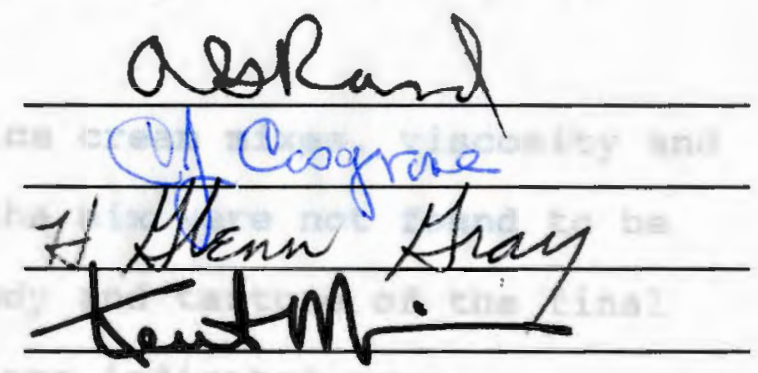

Dean of the Graduate School

UNIVERSITY OF RHODE ISLAND

1989 


\section{ABSTRACT}

A low lactose, sucrose-free, fat-free chocolate frozen dessert was developed. This was achieved by combining polydextrose $-\mathrm{N}$ as bulking agent, acesulfame- $\mathrm{K}$ as sweetener and a microcrystalline cellulose based stabilizer. The product that was developed contained 95 calories per 100 grams.

Lactose reduction of $96 \%$ was achieved in all milk products that were used when liquid lactase enzyme was added at, $3.5 \%$ rate.

The frozen dessert mix that was developed, when flavored with vanilla or strawberry flavoring agents, gave a product with acceptable body and texture, but unacceptable flavor.

As opposed to regular ice cream mixes, viscosity and water activity readings of the mix were not found to be related to the quality of body and texture of the final product, while instron readings indicated some correlation. 


\section{PREFACE}

This thesis consists of Manuscript 1 and Appendices A, B, and C. This thesis is written according to the style accepted by the Journal of Food Science. 
TABLE OF CONTENTS

Page

THESIS ABSTRACT

PREFACE

TABLE OF CONTENTS iv

IIST OF TABLES vi

MANUSCRIPT I - THE FORMULATION OF PREMIUM-STYLE ICE MILK, LOW IN LACTOSE, SUGAR AND FAT. INTRODUCTION

MATERIALS AND METHOdS $\ldots \ldots \ldots \ldots \ldots \ldots \ldots 7$

RESULTS AND DISCUSSION $\ldots \ldots \ldots \ldots \ldots \ldots \ldots$

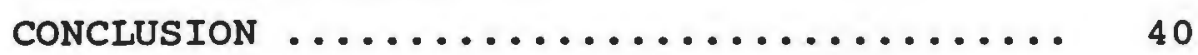

RECOMMENDATIONS FOR FURTHER RESEARCH ..... 42

REFERENCES $\ldots \ldots \ldots \ldots \ldots \ldots \ldots \ldots \ldots \ldots \ldots \ldots \ldots$

APPENDIX A - SENSORY EVALUATION SCORE CARD ...... 48

APPENDIX B - REVIEW OF CURRENT IITERATURE

Polydextrose ................ 50

Acesulfame-k .............. 56

Sherex $302 \ldots \ldots \ldots \ldots \ldots \ldots \ldots \ldots . \ldots \ldots$

obesity ....................... 61

Diabetes Mellitus ............ 63

Lactose Intolerance $\ldots \ldots \ldots \ldots \ldots \ldots 66$ 
Ice Cream and Other Frozen Desserts .. 70

APPENDIX C - National Ice Cream and Yogurt

Retailers Association Project ..... 80

BIBLIOGRAPHY $\ldots \ldots \ldots \ldots \ldots \ldots \ldots \ldots \ldots \ldots \ldots \ldots \ldots \ldots \ldots$ 
LIST OF TABLES.

Page

1 A Standard Vanilla Ice Cream Formulas.......... 18

1B Sensory Evaluation Mean Values for Standard

Vanilla Ice Cream Formulas............... 18

2A Lactose Reduced Ice Cream Formulations with

Varied sucrose Levels.................. 19

2B Sensory Evaluation Mean Values for Lactose

Reduced Ice Cream Formulations with Varied

Sucrose Levels..................... 19

3A Low-Lactose, Sucrose-Free Ice Cream Formulas with Varied Levels of Acesulfame-K......... 21

3B Sensory Evaluation Means for Low-Lactose,

Sucrose-Free Formulas with Varied Levels of

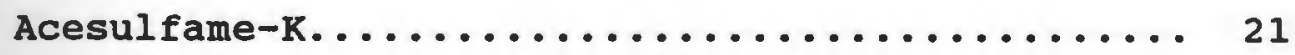

4A Low-Lactose, Sucrose-Free, Acesulfame-K

Sweetened Formulations with Varied Levels

of Polydextrose-N..................... 23

4B Sensory Evaluation Mean Values for Low-Lactose, Sucrose-Free, Acesulfame-K Sweetened Formulas with Varied Levels of Polydextrose-N.......... 23

5A Low-Lactose, Sucrose-Free, Acesulfame-K

Sweetened Formulas with Varied Levels

of Fat and Polydextrose-N............... 24 
5B Sensory Evaluation Mean Values for Low-Lactose Sucrose-Free, Acesulfame-K Sweetened Formulas with Varied Levels of Fat and Polydextrose-N.... 24 6A Low-Lactose, Sucrose-Free, Acesulfame-K

Sweetened Formulas with 4.5 and 08 Fat content.. 26 6B Sensory Evaluation Mean Values for Low-Lactose Sucrose-Free, Acesulfame-K Sweetened Formulas with 4.5 and $0 \%$ Fat Content........ 26 7 Sensory Evaluation Mean Scores for Body/Texture and Penetration Force Values for Standard Ice Cream and Fat-Free Formulations Containing New Ingredients...... 29 8 Sensory Evaluation Mean Scores for Body/Texture and Penetration Force Values for Formula 606 with Various Levels of

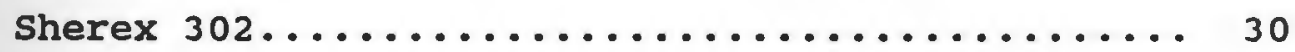
9 Low-Lactose, Sucrose-Free, Fat-Free Formula $697 \ldots \ldots \ldots \ldots \ldots \ldots \ldots \ldots \ldots \ldots \ldots \ldots \ldots \ldots$ 10 Sensory Evaluation Mean Values for Formulas 697 and $401 \ldots \ldots \ldots \ldots \ldots \ldots \ldots \ldots \ldots$ 11 Low-Lactose, Sucrose-Free, Fat-Free, Chocolate Frozen Dessert (Formula 801)........ 34 12 Sensory Evaluation Mean Values for Formulas 801 and 401 and for Three Commercial Chocolate Ice Cream Products.............. 35 
13 Water Activity, Viscosity and Penetration Force Values for Standard Vanilla Ice Cream Formulas with Various Total Solids Levels...... 38 14 Penetration Force Values for Formulas 401 , 697 and 801 and Three Commercial Chocolate Ice Cream Products.............. 39 15 Advantages and Limitations of Various Ice Cream Constituents................ 75 


\section{MANUSCRIPT 1}

THE FORMULATION OF PREMIUM-STYLE ICE MILK, LOW IN LACTOSE, SUGAR AND FAT 


\section{INTRODUCTION}

Ice cream and ice milk are frozen dairy products made by freezing a formulated mix while agitating in order to introduce air and ensure uniformity and consistency. The exact composition of the mix varies according to the type of product. However, a mix would generally be composed of a combination of dairy products, sweetener (in dry or liquid form) and water; it may also include eggs, flavorings and stabilizer and/or emulsifier, all of wholesome edible material (Arbuckle, 1986). In the United States, ice cream and ice cream related products are defined by U.S. Government standards (Code of Federal Regulations, 1982).

The first wholesale ice cream industry in the U.S. was established in 1851 in Baltimore, Maryland and by 1920 the value of ice cream as an essential food was generally recognized (Arbuckle, 1986). Since then, ice cream and all related products have become unusually popular. Annual production of ice cream in the U.S.for 1987 reached 931,398 million gallons, and ice cream related products - frozen milk, ice milk, frozen yogurt etc.- reached 477,469 million gallons (Elliott, 1988; 
I.I.C.A., 1988). These figures put the U.S. in first place world wide for production of ice cream (Arbuckle, 1986). surveys which investigate ice cream's popularity, refer to it as the "Great American Dessert". In hotels and restaurants ice cream is served more often than all other desserts available (Arbuckle, 1986 and Leeder, 1981).

Ice cream and the food products related to it, are nutritious, palatable, healthful and relatively inexpensive. The energy and nutrient values of ice cream depend directly upon the ingredients from which they are made. An average ice cream product will contain milk products, stabilizers, flavoring and other additives like nuts, eggs, fruits etc. Ice cream products are excellent sources of high quality protein. They are good suppliers of calcium, phosphorus, thiamin, riboflavin, vitamin A, vitamin $D$ and other essential nutrients (Bowers and Church, 1985).

What makes ice cream products so popular, and distinguishes them from all other desserts, is the combination of sweetness and the refreshing effect of the fat as a creamy, rich taste. Ironically, the factors that make frozen dairy products delicious and widely desirable are also the ones that raise its price and make it unhealthy for some diet conscious consumers (Anonymous, 1989a). These two major components result in 
the elimination of this food from the diets of millions of Americans that suffer from diabetes and/or obesity (Caliendo, 1987 ; N.I.H., 1987).

Another prominent ingredient in ice cream products is lactose, a disaccharide which is the single largest naturally occuring nutrient found in mammalian milk (crede, 1985). The presence of lactose in dairy products forces close to 60 million Americans with lactose intolerance to exclude such products from their diets in order to avoid the gastrointestinal problems (Skinner and Martems, 1987).

In addition to diabetic, obese and lactose intolerant individuals, other smaller groups of people are also restricted or discouraged from consuming sugar containing products such as ice cream. These include people who suffer from hyperglycemia, hypocholesterolemia, dental plaque and oral diseases (Dahlqvist, 1984; Bowen, 1984). Consumers are better informed on the subject of diet and health which leads them to look for low fat/low calorie foods (Mermelstein, 1989). Diet conscious consumers - for health or cosmetic reasons - constitute a large and growing portion of the market; "calorie reduction has become an obsession in the 1980's", according to Hendley and Seymour (1988). The "lite" versions of frozen dairy products constitute almost $1 / 3$ of the total frozen dairy 
production for the last twenty years (U.S.D.A., 1987; I.I.C.A., 1988)

To satisfy this market, the dairy industry has introduced a variety of new products. These products are artificially sweetened, sucrose-free ice milk, frozen yogurt, sherbet, water ices, etc. There are products low in fat and some calories for obese people, products without sucrose for diabetics, or products low in lactose for the lactose intolerant consumers.

Careful review of the consumption figures for frozen dairy products during the last ten years (U.S.D.A., 1987; I.I.C.A., 1988), reveals that the only significant increase has occurred with frozen yogurt ( $600 \%$ increase ), while products like ice milk or sherbets, remained at constant levels. Only mallorine-type products showed significant decrease in consumption ( $80 \%$ decrease) (I.I.C.A., 1988).

All products mentioned above constitute the market which attempts to appeal to the diet/calorie conscious consumer. The basic difference between the three is that flavor and texture of frozen yogurt comes closer to that of ice cream, while it is significantly lower in fat and some calories. On the other hand, ice milk has more fat but less calories than frozen yogurt. Finally, the 
sherbets lack the thick rich taste of ice cream, but have no fat and less colories than the other two products. Reviewing the above information demonstrates that among the ice cream related products, only frozen yogurt, which has flavor and texture close to that of ice cream, has shown significant increase in consumption figures. This indicates that consumers will not easily accept a product that deviates considerably from ice cream in taste and texture. Products that are out in the market though, do not combine all three desirable characteristics into one product - low lactose, low fat and sugar free. These trends are indicative that the market would be receptive to frozen dairy products significantly lower in calories, fat and lactose than ice cream, but still taste "like the real thing".

The purpose of this study is to develop a product that will have body, texture and taste as close as possible to that of ice cream, while being sucrose-free, low in fat and low in lactose. For this, a combination of new products and current food technology will be used. New sweeteners, stabilizers, flavors and bulking agents will be tried in various formulations in order to develop an "ice cream-like" product which could serve as a safe alternative for those individuals who must or want to maintain certain diet regimens. 


\section{MATERIALS AND METHODS}

\section{MATERIALS.}

Homogenized/pasteurized milk was used throughout this study. Milk was donated by East Greenwich Dairy, cranston, RI.

"Low-heat" non-fat dry skim milk (NDM) was purchased from Land-o-Lakes Dairy, Minneapolis, MN. Polydextrose-N was donated by Chemical Division, Pfizer Inc., New York, N.Y.

Maxilact L-2000 liquid lactase enzyme was donated by GB Fermentation Industries Inc., Des Plains, IL.

Egg yolk solids were donated by National Egg Products, Div. of Corbett Enterprises, Inc., Social Circle, GA.

Two different stabilizers were used during this research: a) Seakem IC912, donated by Marine colloids Division, Philadelphia, PA. This was a carrageenan based material. b) Sherex 302, donated by Microlife-mpi Inc., Rochester, MN. This was a microcrystalline cellulose (MCC) based product, containing not only stabilizer but 
emulsifying agents as well (see "Sherex 302", under Appendix B) .

Acesulfame-K was donated by Hoechst Celanese Corporation, North Somerville, NJ.

The ice cream freezer used for this investigation was a Taylor, model 103, manufactured by Taylor, Rockton, IL.

The homogenizer used during this project was a Gaulin 15M-8BA model, by Manton Gaulin Mfg. Co., Everett, MA. This is a two stage machine, which can process up to 10 liters of mix at pressures as high as 11,000 psi.

Water activity of the samples was measured with a Beckman Humidat-IC I model, by Beckman Industries Inc., Cedar Grove Operations, Cedar Grove, NJ.

For the instron readings, an Instron 1122 model was used, manufactured by Instron Corporation, springfield, N.J. 07081 .

Viscosity readings were taken with a Brookfield Digital viscometer RVTD model, Brookfield Engineering Laboratories, Stoughton, MA.

The determination of lactose hydrolysis was made with a YSI model 23A, glucose analyzer, manufactured by Yellow Springs Instruments Co., Yellow springs, OH.

The flavorings tried during this study were: natural and artificial chocolate and strawberry, and vanilla extract, donated by Globe Extracts Co., New York, NY. 
Vanilla $\mathrm{PFICO}_{2}$ and Vanilla OLEOCAL, were donated by Pfizer Inc., New York, NY. The natural vanilla extracts as well as the cocoa powder used were purchased locally. 
The emulsifiers "Dur-Lo" and "Ice \#2" were donated by Durkee Industrial Foods Corporation, Cleveland, OH.

\section{METHODS}

A. Ice Cream Mix Formulation. Five different vanilla ice cream formulas were prepared, and one was chosen as the standard. After the standard formula was chosen, lactose was hydrolysed in all milk products used, and the sucrose content of the standard formula was adjusted in order to maintain a constant sweetness.

The next step consisted of substituting Acesulfame-K

for sucrose. The percentage of the artificial sweetener required in the ice cream formula, in order for the final product to have the same sweetness level determined in the previous step was studied. Polydextrose-N was incorporated into the formula during the next phase of the research.

The fat content was then gradually reduced in an effort to determine the lowest acceptable level. While fat was being reduced, higher levels of polydextrose-N were introduced in the formula to compensate for the solids reduction. Also, various types of gums, emulsifiers and stabilizers were tested for better 
results.

B. Ice Cream Processing: All ice cream formulations were prepared in the same general way (Arbuckle, 1986). The Ingredients were first weighed separately and dry ingredients (MSNF, sweetener, stabilizer, egg yolk solids, etc.), were mixed together. Liquid milk ingredients were heated up to $30^{\circ} \mathrm{C}$ and all ingredients were added to the milk, and the mix was then blended until all ingredients were dissolved. A Waring blendor was used along with a rheostat in order to achieve the desired vortex without any foaming of the mix.

The mix was then batch pasteurized at $69^{\circ} \mathrm{C}-71^{\circ} \mathrm{C}$ for $30 \mathrm{~min}$.

Immediately after pasteurization, the mix was homogenized at $500 / 2500$ psi.

Following homogenization, the flavor was added, and the mix was then cooled in a walk-in refrigerator at $1^{\circ} \mathrm{C}$ $-3^{\circ} \mathrm{C}$

When the mix reached $4^{\circ} \mathrm{C}-5^{\circ} \mathrm{C}$, it was transfered to the ice cream freezer. Freezing was conducted until the product reached a temperature between $-5^{\circ} \mathrm{C}$ and $-7^{\circ} \mathrm{C}$, and an overrun of $55 \%$.

The overrun was calculated by weight (Arbuckle, 1986), using the following formula: 
overrun $z=$

mix weight of 1 gal - weight of 1 gal of product

weight of 1 gal of product

When drawn from the freezer, the product was packed in one-pint plastic containers, covered and allowed to harden at $-23^{\circ} \mathrm{C}$ overnight. For this process, samples were placed very close and against the fans of the freezer blowers, in order to minimize the time required for hardening.

c. Lactose Hydrolysis: Whole milk, skim milk, cream and dry skim milk were formulated and mixed together for treatment with lactase enzyme prior to the preparation of the ice cream mix. Maxilact L 2000 liquid lactase was added at $3.5 \%(\mathrm{w} / \mathrm{v})$, and the milk base was allowed to hydrolyze at $1^{\circ} \mathrm{C}-3^{\circ} \mathrm{C}$ for $24 \mathrm{hr}$.

The percent of lactose hydrolyzed in each mix was determined by the amount of glucose produced due to the hydrolysis (De Angelis, 1979). Glucose content of the mix was determined before and after lactose hydrolysis with 
the YSI Glucose Analyzer in $\mathrm{mg}$. The difference gave the glucose produced, indicating the amount of lactose hydrolyzed.

The percent of lactose content in each formulation was datermined based on the proportional contribution of the following lactose concentrations : Whole milk $4.6 \%$ lactose, skim milk 4.9\%, heavy cream $2.9 \%$ and dry skim milk 50\% (Walstra and Jenness, 1984).

The formula for calculating the percentage of lactose hydrolyzed in milk was as follows:

lactose hydrolysis=

moles of glucose generated due to hydrolysis. X 100

moles of lactose in mix before hydrolysis

D. Sensory Evaluation and Analysis: one day prior to each sensory test, products were tempered in a freezer at $-15^{\circ} \mathrm{C}$. Two-ounce disposable cups were labeled with the code number of each formula tested. One scoop of each sample was placed in each cup. An average of $15-20$ panelists were asked to look, taste and score the samples. Samples were given to the panelists in a random 
order, and they were asked to rate these using the score card shown in Appendix A. The quality factors examined were those of flavor, body and texture, color, sweetness and melting. For melting qualities, one scoop of each sample was placed in a plate and allowed to melt at room temperature. A size $24(18 / 8)$ scoop was used (wittinger and Smith, 1986; Arbuckle, 1986).

The sensory evaluation results were statistically analyzed. The analysis of variance test was first done on the means of the total scores of the samples tested. This indicated the existence of significant difference. Following the analysis of variance, Duncan's multiple range test was applied at the 0.05 (5\%) level. This test showed where the statistical difference occured. Means that were significantly different have been designated with different letters (Tables 1A through 13). E. Physical Tests: Physical tests were made not only on the final product but also on the mix itself. These objective tests were conducted in conjunction with the subjective (sensory) tests, in an effort to obtain as complete an analysis as possible of the products.

a) Viscosity. The viscosity of each mix was measured by a Brookfield viscometer, at $23^{\circ} \mathrm{C}$, after the mix had been homogenized. viscosity was expressed in centipoise by the following formula: 
(viscometer reading) $\times$ (spindle factor) = centipoise. The following spindles were used: spindle \#2 (factor 4) and spindle \#3 (factor 10). The instrument was set at 100 RPM.

b) Instron. All samples tested were in one pint containers. A cylindrical, flat-end probe was used, with diameter of $8 \mathrm{~mm}$. Samples were penetrated in the center of the surface. The instron macine was set at the following settings:

$$
\begin{aligned}
& \text { Penetration distance } \ldots \ldots \ldots .40 \mathrm{~mm} \\
& \text { Cross head speed } \ldots \ldots \ldots \ldots \ldots .50 \mathrm{~mm} / \mathrm{min} \\
& \text { Chart speed } \ldots \ldots \ldots \ldots \ldots \ldots .600 \mathrm{~mm} / \mathrm{min} \\
& \text { Full scale } \ldots \ldots \ldots \ldots \ldots \ldots . .5 .0 \mathrm{~kg}
\end{aligned}
$$

c) Water activity $\left(a_{w}\right)$. The water activity of homogenized mix was determined at room temperature. A Beckman Humidat IC-1 was used and standarized at $75.2 \%$ with a saturated solution of sodium chloride (Beckman, 1982). Readings were recorded when instrument indication was stabilized within $0.1 \%$

F. Determination of Caloric Value, The Nutritionist III computer program (copyright 1985), produced by N-Squared Computing (Silvertone, OR), was used for the determination of the caloric value of formulas developed. Products that were recently developed ( polydextrose, etc. ), had to be added to the program, along with their 
nutritional information, since they were not included in the data base of the latest version of the program. Chemical analysis was also used for calculating the caloric value. Fat was determined by the modified Pennsylvania test (M.I.F., 1959), while protein and total solids were determined by A.O.A.C. procedures (A.O.A.C.,1980a; A.O.A.C., 1980b). Carbohydrates were determined by subtracting fat, protein and moisture from the total solids.

\section{RESULTS AND DISCUSSION}

\section{A) Ice Cream Manufacture.}

In order to establish a standard reference ice cream, five original formulations (Arbuckle, 1986) were made as shown in Table $1 \mathrm{~A}$, processed into ice cream, and subjected to sensory evaluation as shown in Table 1B. The formulas 401 and 634 received similar and significantly higher total scores. These two formulas were the ones with the highest fat and total solids (T.S.) content. Lower fat and T.S. levels (formulas 347, 281 and 835), affected the flavor mainly, leading to lower total sensory scores. Formula 401 was ultimately 
selected as the standard reference ice cream formula, due to the higher score for body and texture. This was considered to be the important characteristic in the development of the new product.

\section{B) Product Development.}

1. Lactose reduction. Due to the fact that the products of lactose hydrolysis, glucose and galactose were sweeter than lactose, the level of sweetness in the low lactose versions of formula 401 were compared as shown in Table 2A. Sensory evaluation analysis found that all formulas were statistically different. By comparing not only the total scores but flavor as well, it was obvious that formula 362 , which contained $11 \%$ sucrose and $96 \%$ lactose hydrolysis, was preferred by the panel.

Formula 401 (Table 1A), contained $13.4 \%$ sucrose, whereas formula 362 (Table 2A), which had $96 \%$ lactose hydrolysis, contained $11 \%$ sucrose. This indicated that a 17.9\% sucrose reduction in the ice cream formulation was possible with lactose hydrolysis. The caloric value of the formula was not reduced, due to the fact that MSNF were added to keep total solids at the same level (42\%). The reduction of lactose should help avoid sandiness of the product, since lactose crystals would be less likely 
TABLE 1A

Standard Vanilla Ice Cream Formulas

\begin{tabular}{lrrrrr} 
Eormula & 347 & \multicolumn{1}{c}{634} & \multicolumn{1}{c}{281} & \multicolumn{1}{c}{401} & 835 \\
Fat(z) & 12.4 & 15.0 & 14.5 & 16.0 & 10.7 \\
CHO(f) & 17.9 & 18.2 & 17.0 & 18.9 & 12.2 \\
Prot.(z) & 4.2 & 5.9 & 5.2 & 5.3 & 3.9 \\
I.S.(z) & 37.8 & 41.8 & 38.7 & 42.0 & 39.8 \\
Sucr.(z) & 13.2 & 14.1 & 15.0 & 13.4 & 12.6 \\
Calories & 200 & 231 & 219 & 241 & 161
\end{tabular}

TABLE 1B

Sensory Evaluation Mean Values for Standard Vanilla Ice Cream

Formulas

\begin{tabular}{lccccc} 
Formula & \multicolumn{1}{c}{347} & 634 & \multicolumn{1}{c}{281} & 401 & 835 \\
flavor & $8.4 \pm 0.9$ & $9.8 \pm 1.0$ & $8.1 \pm 1.3$ & $9.7 \pm 0.9$ & $7.9 \pm 1.7$ \\
body/texture & $4.1 \pm 2.1$ & $4.4 \pm 1.7$ & $4.6 \pm 0.6$ & $4.9 \pm 1.0$ & $4.1 \pm 1.3$ \\
melting & $4.8 \pm 0.3$ & 5.0 & $4.9 \pm 0.3$ & 5.0 & 5.0 \\
Color & $4.2 \pm 1.7$ & $4.6 \pm 0.8$ & $4.5 \pm 1.0$ & $4.7 \pm 0.8$ & $4.1 \pm 1.5$ \\
TOTAL & $21.5 \pm 1.2^{c}$ & $24.3 \pm 0.9^{a}$ & $22.2 \pm 1.0^{b}$ & $24.4 \pm 0.8^{a}$ & $21.1 \pm 1.6^{c}$
\end{tabular}


TABLE 2A

Lactose Reduced Ice Cream Formulations

With Varied Sucrose Ievels.

\begin{tabular}{lrrrrrr} 
Eormula & 665 & \multicolumn{1}{c}{733} & 362 & 6776 & 628 & 1465 \\
Fat (8) & 16.2 & 16.1 & 16.2 & 16.2 & 16.1 & 16.0 \\
CHO(z) & 19.1 & 19.0 & 17.8 & 17.2 & 17.3 & 17.2 \\
Prot.(8) & 5.0 & 5.6 & 6.1 & 6.3 & 6.5 & 7.1 \\
T.S.(8) & 42.2 & 42.0 & 41.9 & 41.5 & 41.5 & 41.0 \\
Sucrose(8) & 15.0 & 13.0 & 11.0 & 10.0 & 8.0 & 6.0
\end{tabular}

TABLE 2B

Sensory Evaluation Mean Values for Lactose Reduced Ice Cream Formulations with Varied sucrose Levels

\begin{tabular}{|c|c|c|c|c|c|c|}
\hline Formula & 665 & 733 & 362 & 6776 & 628 & 1465 \\
\hline flavor & $7.9 \pm 2.1$ & $8.8 \pm 1.5$ & $9.4 \pm 0.6$ & $9.2 \pm 1.9$ & $7.9 \pm 1.2$ & $7.9 \pm 2.6$ \\
\hline$b / t$ & $4.9 \pm 0.9$ & $4.7 \pm 1.0$ & $4.8 \pm 0.7$ & $4.1 \pm 1.6$ & $4.2 \pm 1.4$ & $3.9 \pm 1.9$ \\
\hline melt. & 5.0 & $4.8 \pm 1.1$ & $4.9 \pm 0.4$ & 5.0 & $4.9 \pm 0.7$ & $4.2 \pm 0.9$ \\
\hline color & $4.8 \pm 1.2$ & 5.0 & 5.0 & $4.8 \pm 0.7$ & $4.9 \pm 1.4$ & $4.6 \pm 1.2$ \\
\hline
\end{tabular}


to form when a higher percentage of MSNF was used (Hendley et al., 1988).

2. Sucrose reduction. The sweetness of acesulfame-k has been reported as approximately 200 times that of sucrose (Anonymous 1986a; Anonymous 1986b). The exact level of sweetness, though, depends on the other ingredients present in the formula, and the way it was processed. In order to establish the correct level of acesulfame-K needed for the substitution of sucrose, five levels of the artificial sweetener were examined as shown in Table 3A. Statistical analysis of the sensory evaluation results clearly indicated that formula 1920 (with $0.06 \%$ acesulfame-K) was preferred. Levels of 0.04 and $0.05 \%$ acesulfame- $K$ were criticized as slightly undersweet and lacking in flavor; levels of 0.08 and $0.1 \%$ acesulfame-K, were thought to be too sweet. The fat level was kept at the $16 \%$ level. Note that in order to keep the total solids at the same level, more MSNF was used.

All formulations for sucrose reduction received low scores for body and texture (Table 3A), and for melting. The body of these products was weak and the texture icy and slightly coarse due to the lack of sucrose, which was eliminated from the formulas. Sucrose contributes not only sweetness and bulk to the product, but also absorbs water, and thus reduces water 
TABLE 3A

Low-Lactose, Sucrose-Free Ice Cream Formulas with Varied Ievels of Acesulfame-K*

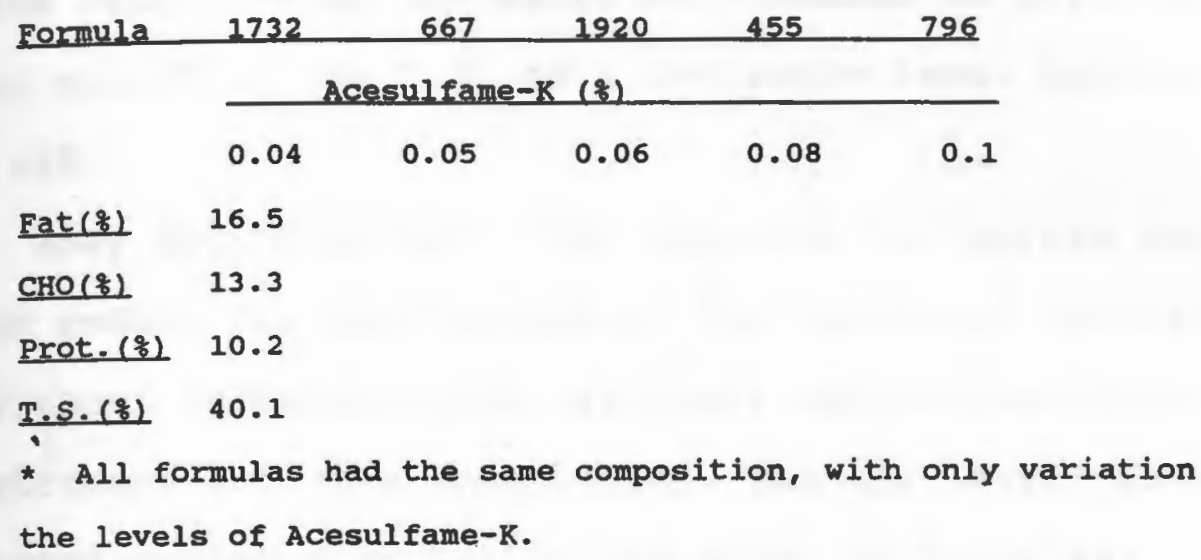

\section{TABLE 3B}

\section{Sensory Evaluation Means for Low-Iactose, Sucrose-Free}

Formulas with Varied Acesulfame-K Levels.

$\begin{array}{lccccc}\text { Eormula } & 1732 & 667 & 1920 & 455 & 796 \\ \text { flayor } & 8.1 \pm 1.9 & 7.9 \pm 1.8 & 8.9 \pm 0.9 & 8.2 \pm 1.2 & 7.8 \pm 1.5 \\ \text { body/textr. } & 2.1 \pm 1.8 & 2.8 \pm 2.0 & 2.7 \pm 1.6 & 2.6 \pm 1.4 & 2.4 \pm 1.2 \\ \text { melting } & 3.7 \pm 1.2 & 3.5 \pm 1.6 & 3.2 \pm 1.4 & 3.4 \pm 0.9 & 3.7 \pm 1.5 \\ \text { color } & 4.8 \pm 0.7 & 4.9 \pm 1.0 & 4.8 \pm 0.9 & 4.8 \pm 0.5 & 4.9 \pm 0.9 \\ \text { ToTaL } & 18.7 \pm 1.7^{\alpha} & 19.1 \pm 1.7^{b} & 19.6 \pm 1.3^{c} & 19.0 \pm 1.3^{b} & 18.8 \pm 1.4^{a}\end{array}$


available to be frozen, which results in small ice crystals and smooth texture. The higher percentage of MSNF, resulted in foamy melt which consequently led to low melting scores. Calories were reduced by a mere 1.5\%, again the reason being the extra MSNF needed to build up the body and bring the T.S. to a desirable level between 40 and $42 \%$

3. Body Modification. The approach to improve the body and reduce the icy texture of the preferred formula 1920, without increasing the calories, was to introduce polydextrose-N into the formulation. The six levels that were tested during formulation are shown in Table 4A. Sensory evaluation shows that the panel gave statistically higher total scores to formula 653, which had $18 \%$ polydextrose-N. This formula received higher total scores and was also scored high for both body and texture and melting. Again, fat was kept at the $16 \%$ level and T.S. between 40 and $42 \%$

4. Reduction of fat content. The fat content of the mix formulation was modified for the low-lactose, sucrose-free formula 653. Three fat levels were compared to $16 \%$ by sensory analysis as shown in Table 5A. All three formulas, 231, 321 and 123, had T.S. between 40 and 42\%. The three major ingredients used in the above formulas, that would contribute to body and texture, were 
TABLE 1A

Low-Lactose, Sucrose-Free, Acesulfame-K Sweetened

Formulations with Varied Levels of Polydextrose-N

\begin{tabular}{|c|c|c|c|c|c|c|}
\hline Formula & 104 & 512 & 653 & 707 & 365 & 932 \\
\hline \multicolumn{7}{|l|}{ Polyd-N } \\
\hline (z) & 22 & 20 & 18 & 16 & 14 & 12 \\
\hline Fat $(z)$ & 16.4 & 16.4 & 16.3 & 16.5 & 16.4 & 16.4 \\
\hline $\mathrm{CHO}(8)$ & 13.4 & 13.7 & 14.1 & 14.4 & 14.9 & 15.2 \\
\hline Prot. ( $(z)$ & 4.5 & 5.0 & 5.7 & 6.4 & 7.0 & 7.6 \\
\hline T.S. (q) & 42.4 & 42.1 & 42.0 & 42.2 & 42.0 & 42.0 \\
\hline
\end{tabular}

TABLE $4 B$

Sensory Evaluation Mean Values for Low-Lactose, Sucrose-Free Acesulfame-K Sweetened Formulas

with Varied Levels of Polydextrose-N

\begin{tabular}{|c|c|c|c|c|c|c|}
\hline Formuls & 104 & 512 & 653 & 707 & 365 & 932 \\
\hline flavor & $9.2 \pm 1.2$ & $9.4 \pm 1.6$ & $9.5 \pm 1.3$ & $9.5 \pm 1.7$ & $8.9 \pm 1.6$ & $8.9 \pm 1.9$ \\
\hline$b / t$ & $3.5 \pm 1.7$ & $4.2 \pm 1.7$ & $4.9 \pm 1.4$ & $4.3 \pm 1.9$ & $3.3 \pm 2.1$ & $3.5 \pm 1.8$ \\
\hline melt. & $4.6 \pm 0.9$ & $4.6 \pm 1.2$ & $4.8 \pm 1.1$ & $4.7 \pm 1.7$ & $4.4 \pm 1.4$ & $4.3 \pm 1.5$ \\
\hline color & $4.8 \pm 0.7$ & $4.9 \pm 0.3$ & $4.8 \pm 0.9$ & $4.7 \pm 0.5$ & $4.8 \pm 1.1$ & $4.2 \pm 1.2$ \\
\hline
\end{tabular}


TABLE 5A

Low-Lactose, Sucrose-Free, Acesulfame-K Sweetened

Formulas, with Varied Levels of Fat and

Polydextrose-N

$\begin{array}{lcccc}\text { Eormula } & 653 & 231 & 321 & 123 \\ \text { Eat (z) } & 16.3 & 10.0 & 5.2 & 3.1 \\ \text { CHO(z) } & 14.1 & 15.3 & 16.2 & 17.1 \\ \text { Prot. (z) } & 5.4 & 7.2 & 7.9 & 8.7 \\ \text { T.S. (z) } & 42.0 & 42.2 & 41.3 & 40.1 \\ & & & & \\ \text { Polyd-N(z) } & 18.0 & 19.1 & 20.0 & 23.2 \\ \text { Acesulf-K(z) } & 0.06 & 0.06 & 0.07 & 0.08\end{array}$

TABLE 5B

Sensory Evaluation Mean Values for Low-Lactose,

Sucrose-Free, Acesulfame-K Sweetened Formulas, with

Varied Levels of Fat and Polydextrose-N

$\begin{array}{lllll}\text { Formula } & 653 & 231 & 321 & 123 \\ \text { flavor } & 9.5 \pm 1.3 & 9.5 \pm 1.6 & 9.0 \pm 1.3 & 6.2 \pm 1.7 \\ \text { body/textr } & 4.9 \pm 1.4 & 4.8 \pm 0.9 & 4.5 \pm 1.0 & 3.2 \pm 0.9 \\ \text { melting } & 4.8 \pm 1.1 & 4.7 \pm 1.5 & 4.7 \pm 1.5 & 3.1 \pm 1.9 \\ \text { color } & 4.8 \pm 0.9 & 5.0 & 4.3 \pm 1.2 & 3.9 \pm 1.5 \\ \text { TOTAL } & 24.0 \pm 1.4^{a} & 24.0 \pm 1.4^{\alpha} & 22.5 \pm 1.4^{b} & 16.4 \pm 1.7^{c}\end{array}$


fat, MSNF, and polydextrose-N. Since fat (which also affects flavor), was being reduced, polydextrose-N and acesulfame-K levels were slightly increased in order to compensate for loss in body and texture and flavor. The results showed that formula 123 , containing $3 \%$ fat received significantly lower scores than formulas 321 and 231 in all four characteristics scored. An off-flavor, followed by an unacceptable after-taste was found in formula 123.

Since the lowest acceptable fat level appeared to be between $5.2 \%$ of formula 321 and $3.1 \%$ of formula 123, two more formulations were prepared, as shown in Table 6A. Formula 884 , containing 4.58 fat, and formula 606 , containing $0 \%$ fat, were tested in order to examine and compare the effects of optimum and complete fat elimination from the formulation. Formula 884 received higher scores for flavor, body and texture and melting than formula 123. The color of the product was still within acceptable levels, although compared to the standard product, it was noticeably darker. This was believed to be due mostly to the lack of fat, the prevalance of polydextrose-N, which contributed a yellowish tinge, and the higher percentage of MSNF. Comparison of the sensory scores for formulas 123 , 
TABLE 6A

Low-Iactose, Sucrose-Free, Acesulfame-K Sweetened Formulas,

with 4.5 and 08 Fat content.

$\begin{array}{lcr}\text { Eormula } & 884 & 606 \\ \text { Fat } & 4.4 & 0.0 \\ \text { cHo } & 16.3 & 15.7 \\ \text { Prot. } & 8.7 & 7.2 \\ \text { T.S. } & 42.1 & 40.9 \\ & & \\ \text { Polyd-N } & 20.5 & 24.0 \\ \text { Acesulf-K } & 0.085 & 0.1\end{array}$

TABIE 6B

Sensory Evaluation Mean Values

for Low-Iactose, Sucrose-Free, Acesulfame-K Sweetened

Formulas, with 4.5 and of Fat content.

$\begin{array}{llc}\text { Eormula } & 884(4.5) \text { fat }) & 606(0.0) \text { fat }) \\ \text { flavor } & 9.1 \pm 1.3 & 6.0 \pm 2.1 \\ \text { body/textr. } & 4.6 \pm 1.7 & 3.0 \pm 1.9 \\ \text { melting } & 4.7 \pm 1.5 & 3.2 \pm 1.4 \\ \text { color } & 4.4 \pm 1.2 & 3.7 \pm 1.5 \\ \text { TotaL } & 22.8 \pm 1.5 & 15.9 \pm 1.8\end{array}$


with $3 \%$ fat, and 606 , with $0 \%$ fat, shows that the flavor and total scores were very close. Both formulas had a weak body as well as an icy texture. Also, an intense off-flavor followed by an unacceptable after-taste was present in the product.

since no additional defects were detected at the $0 \%$ fat level, a decision was made, to investigate the potential to improve the fat-free product.

5. Texture improvement. Both literature (Arbuckle, 1986), and local industry people suggested incorporation of live culture into the formula in order to improve the texture and flavor. These suggestions were rejected as this research was not focused on "frozen yogurt" type of products.

The need for different types of stabilizers and/or emulsifiers was realized at this point. Various formulations were tried in an effort to correct the defects in body and texture of the fat-free formulations. Using formula 606, containing $0 \%$ fat as a basis, various emulsifiers and stabilizers were tested. Formulations developed were judged for body and texture. Also, the penetration force was measured for a more objective evaluation.

Emulsifiers "Ice \#2" and "Dur-Lo" and stabilizer "Sherex 302" were used at levels suggested by the 
anufacturers. As shown in Table 7 , neither of the two new emulsifiers contributed any improvements, when compared to the carrageenan-based Seakem IC 912. The body/texture scores were about the same for all three products, with only slight improvement in the value of ponetration force. Stabilizer "Sherex 302" gave a comparatively better body, close to a perfect score of 5 , but was too hard and dense, as indicated by a doubling of the penetration force value.

The recommended levels of Sherex 302 for low or non fat frozen desserts were between 0.72 and $0.80 \%$ (Microlife Inc., 1989). These levels were too high for this formulation, and resulted in an improved but excessively hard body. Lower percentages of Sherex 302 were tested (Table 8), by both sensory and penetration values. It was clear that a reduction in stabilizer decreased the penetration values, which were all higher than the standard ice cream (Table 7). However, a decrease in Sherex 302 did improve the body and texture Agnificantly at the $0.45 \%$ level. This led to the basic formula 697 (Table 9). Egg yolk solids were not included in this formula. This was done, not only to reduce the cholesterol level of the product, but also because the mulsifying effects of the egg yolk solids were replaced 
TABLE 7

Sensory Evaluation Mean Scores for Body/Texture

and Penetration Force Values for Standard Ice cream and Fat-Free

Formulations containing New Ingredients.

Score for

Body/Texture
Penetration Force

$(\mathrm{Kg})$

Formula 606

with:

Seakem IC $912(0.058)$

$3.0 \pm 1.9$

1.9

Ice \#2 (0.25\%)

$3.1 \pm 1.6$

2.2

Dur-Io (5.0\%)

$3.0 \pm 1.9$

2.0

Sherex $302(0.7 \%)$

$4.1 \pm 1.6$

4.5

Formula 401 with

Seakem IC $912(0.04 \%)$

$4.9 \pm 1.0$

3.2 


\section{TABLE 8 \\ Sensory Evaluation Mean Scores for Body/Texture, and Penetration Force Values, for Formula 606 with Various \\ Levels of Sherex 302 .}

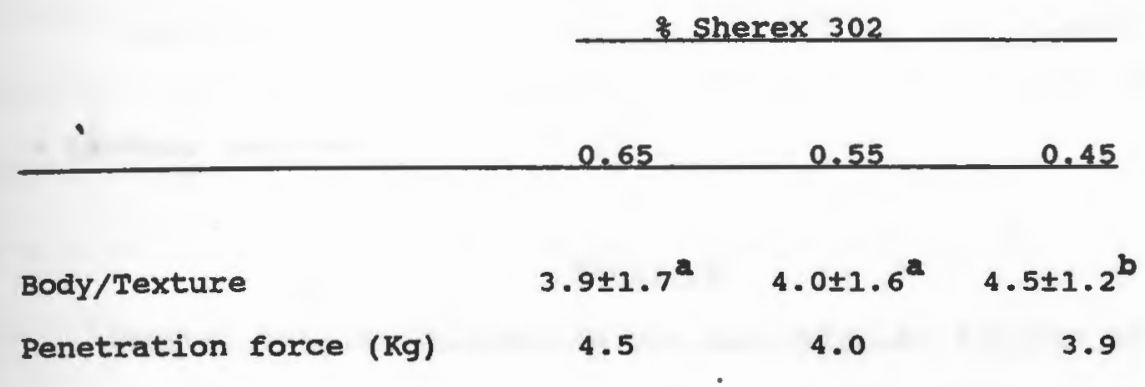


TABLE 9

Low-Lactose, Sucrose-Free, Fat-Free Formula 697

composition ( $\%$ )

$\begin{array}{lr}\text { Fat }(\xi) & 0.0 \\ \text { CHO(f) } & 15.2 \\ \text { Prot. (z) } & 7.3 \\ \text { T.S. (z) } & 40.5\end{array}$

* Lactose reduced.

\begin{tabular}{lc} 
Ingredients ( () & \\
\hline Skim milk * & 57.0 \\
MSNF * & 15.2 \\
Polydextrose-N & 24.5 \\
Acesulfame-K & 0.9 \\
Sherex 302 & 0.45 \\
Vanilla & 2.0 \\
& 100.05
\end{tabular}

TABLE 10

Sensory Evaluation Mean Values for Formulas 697 and 401

\begin{tabular}{lll} 
Eormula & \multicolumn{1}{c}{697} & \multicolumn{1}{c}{401} \\
flavor & $5.8 \pm 1.2$ & $9.8 \pm 0.7$ \\
body/textr. & $4.5 \pm 1.5$ & $4.8 \pm 0.9$ \\
melting & $4.2 \pm 1.7$ & 5.0 \\
color & $4.5 \pm 0.9$ & $4.8 \pm 1.1$ \\
TOTAL & $19.0 \pm 1.5$ & $24.4 \pm 0.9$
\end{tabular}


by the emulsifiers included in sherex 302 .

The contribution of emulsifiers to the body and texture of a fat-free product was not clear. Arbuckle (1986) and Fennema (1985) mentioned that some stabilizers work better in the presence of certain emulsifiers, which may be the reason for the effects found in this study. since formula 697 was accepted as the one with a body and texture compatible to the standard formula 401, both were compared by sensory evaluation (Table 10). The formula 697 product had a creamy, smooth mouthfeel which was rated similar to the standard 401 formula in body and texture scores. The darker color, compared to the standard product, did not receive low scores indicating that it was accepted by the panel. Although formula 697 delivered a pleasent melting feeling on the tongue, it received low scores for melting. That was due to the fact that formula 697 had a foamy melt. The melt separated into two layers, indicating that the melted mix was not homogeneous. The upper layer was lighter in color and foamy, whereas the lower one was darker, without any Indication of air bubbles. This "defect", was not picked up by the panel during the sensory evaluation and did not affect the feel of the frozen product on the tongue. The one remaining major problem was flavor. The sensory score was inferior to the standard due to an intense 
off-flavor. This was apparently due to the high level of lydextrose-N used in the final formulation.

6. Flavor improvement. New flavoring agents were tested, in an effort to improve this aspect, since the natural vanilla extract used was not adequate. Artificial chocolate and strawberry and vanilla $\mathrm{PFICO}_{2}$ and vanilla OLEOCAL were tried without any improvement in the flavor score of formula 697, already shown in Table 10.

since vanilla was a very fine flavor, by nature, cocoa powder was incorporated into formula 697 in conjunction with vanilla, and resulted in the final formulation 801 , shown in Table 11.

The formula 801 product was compared with three commercial chocolate ice cream products by sensory evaluation. As shown in Table 12, formula 801 proved to be acceptable by the panelists, who detected no off-flavor or aftertaste. Although melting was improved, compared to formula 697, it was still marked down due to slight foaming. Unlike formula 697 , there was no separation detected to the melt of formula 801 . Some cocoa particles precipitated, though, when the product was melted. Comparing the scores in Table 12, it was clear that formula 801 received scores for flavor, body and texture and color, that were comparable to commercial ice cream. This new product was not significantly 
TABLE 11

Low-Lactose, Sucrose-Free, Fat-Free, Chocolate

Frozen Dessert. (Formula 801)

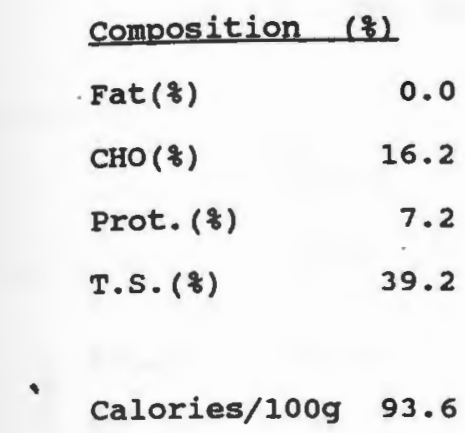

\begin{tabular}{lc} 
Ingredients & $(\xi)$ \\
\hline Skim milk * & 52.3 \\
MSNF * & 15.4 \\
Polydextrose-N & 23.3 \\
Acesulfame-K & 0.9 \\
Sherex 302 & 0.45 \\
Vanilla & 1.0 \\
Cocoa powder & 1.8 \\
water & 5.0 \\
& 100.01
\end{tabular}

* Lactose reduced. 
TABTE 12

Sensory Evaluation Mean Values for Formulas 801 and 401 and for Three commercial chocolate Ice cream Products.

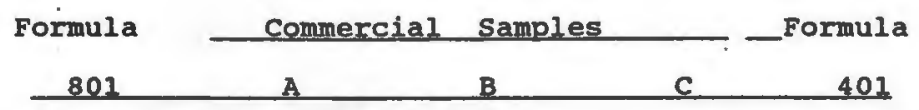

$\begin{array}{llllll}\text { flavor } & 9.6 \pm 1.7 & 9.8 \pm 1.5 & 9.5 \pm 1.4 & 9.0 \pm 1.0 & 9.7 \pm 0.9 \\ \text { b } / t & 4.7 \pm 1.6 & 4.4 \pm 1.9 & 4.7 \pm 0.9 & 4.3 \pm 1.4 & 4.9 \pm 1.0 \\ \text { melting } & 4.4 \pm 1.1 & 4.2 \pm 1.3 & 4.8 \pm 1.2 & 5.0 & 5.0 \\ \text { color } & 4.8 \pm 0.7 & 4.9 \pm 0.7 & 5.0 & 4.0 \pm 1.4 & 4.7 \pm 0.8 \\ \text { TOTAL } & 23.5 \pm 1.5^{a} & 23.3 \pm 1.6^{a} & 24.0 \pm 1.3^{b} & 22.3 \pm 1.3^{c} & 24.4 \pm 0.8^{b}\end{array}$


afferent from commercial sample $A$, but was significantly superior to commercial sample $c$. One commercial product, sample B and reference formula 401 were the only samples rated statistically superior to formula 801 .

\section{B) Physical Tests.}

since sensory evaluation tests would be subjective by nature, physical tests were also run for additional evaluation of the products. Tests were run on both the mixes, before freezing, in an attempt to replicate the physical characteristics of the standard mix, and on the final frozen products to evaluate changes in formulation.

1. Viscosity. The standard mix, formula 401 , gave viscosity readings of 110 centipoise using an "H3" size spindle on a Brookfield viscometer. Initially, when the standard formulas were tested, low viscosity readings indicated that the final product whould have a weaker body, after freezing. This is shown in Table 13, where lower penetration force values indicate a weaker body. ponsequently the aim was to replicate these readings in the subsequent test batches. Unfortunately, during "texture improvement", when polydextrose-N was moorporated in the formulation, the behavior of the mix 
was not found to be the same. Mixes with significantly lower viscosity readings, gave extremely hard products. It was concluded that mix viscosities would not be a predicting indicator for the potential of the mix once new Ingredients, like polydextrose-N and sherex 302 , were introduced.

2. Water Activity. Mixes were tested for water activity $\left(a_{w}\right)$ after homogenization and after cooling to room temperature. As shown in Table 13, there was no clear indication from water activity values for the potential body and texture of the mixes. Although water activity readings of some mixes were quite close, deviating by only $1.2 \%$ ( from 91.7 to $92.9 \%$ ), the actual body and texture of the final products varied considerably, ranging from too hard to soft and coarse. Thus, water activity values of the mixes were not proven to be an accurate method of assesing body and texture of the final products.

3. Instron. In order to objectively evaluate the body and texture of the finished products, the penetration force was measured by using as Instron 1122 model, equiped with a "round head" probe. This proved to be a useful method for assessing the hardness of products. Penetration force readings, listed in Table 14, demonstrate higher readings for the experimental 
TABLE 13

Water Activity, Viscosity and Penetration Force

Values for standard Vanilla Ice Cream Formulas

With Various Total Solids Levels.

\begin{tabular}{|c|c|c|c|}
\hline Nater Activity & Viscosity & Penetration & Total Solids \\
\hline$\frac{\left(a_{w} z\right)}{z}$ & (centipoice) & Force $(\mathrm{Kg})$ & (z) \\
\hline 92.4 & 230 & 7.30 & 51.0 \\
\hline 92.9 & 110 & 3.20 & 42.0 \\
\hline 91.7 & 80 & 2.95 & 35.0 \\
\hline 91.9 & 40 & 1.50 & 27.0 \\
\hline
\end{tabular}




\section{TABLE 14}

metration Force Values for Formulas 401,697 and 801 and Three Commercial Chocolate Ice Cream Products.

\section{Penetration}

Formula

Force $(\mathrm{kg})$

$\begin{array}{ll}401 & 3.20 \\ 801 & 3.95 \\ 697 & 3.90 \\ 747 & 3.15 \\ 049 & 2.30 \\ 208 & 2.95\end{array}$


formulas ( 801 and 697 ), which indicates that at the same comperature the products were harder. This was vaneficial, since the products were not found to be too hard. When soft enough to eat, the experimental products would be at a lower temperature, compared to standard commercial ice cream, and thus would have a more intense sweetness and flavor. Also, the fact that there were no fluctuations on the Instron printouts, indicates that the products were evenly packed, and body was consistent throughout the 4 centimeters of penetration.

\section{CONCLUSIONS.}

The following conclusions can be made as a result of this thesis research project.

1. Lactose levels were reduced by $96 \%$, in $24 \mathrm{hrs}$. at $3 \frac{3}{2} \mathrm{C}$, in ice cream mix, when treated with Maxilact L-2000 liquid lactase enzyme added at a $3.5 \%$ concentration.

2. When low-lactose milk products (whole milk, skim milk, cream), were used as ingredients in standard plain vanilla ice cream, sucrose content could be reduced from 
13.4 to $11.0 \%$ of the mix. This represented a $17.9 \%$ reduction. This produced an acceptable low-lactose ice cream product.

3. When acesulfame-K (Sunette), was used as a substitute sugar in low-lactose ice cream mix, a opcentration of $0.06 \%$ provided sweetness comparable to 118 sucrose and an acceptable ice cream product.

4. When sucrose was completely substituted with acesulfame-K in a plain vanilla low-lactose ice cream formula, poor body and texture characteristics resulted.

5. Polydextrose-N, when added at a level of $18.0 \%$, was found to restore the otherwise unacceptable body and texture in a low-lactose, sugar-free, acesulfame- $K$ sweetened ice cream product.

6. Polydextrose-N and a carrageenan stabilizer were not sufficient to produce an acceptable body and texture in a low-lactose, sugar-free, acesulfame- $K$ sweetened and fat-free frozen dessert.

7. The microcrystalline cellulose based stabilizer Sherex 302, at a $0.45 \%$ level, in conjunction with $24 \%$ polydextrose-N, gave an acceptable body and texture to the low-lactose, sugar-free, fat-free frozen dessert. An intense off-flavor was present in this new frozen dessert product, making it unacceptable.since none of the ingredients used had any off-flavor, the problem may have 
been due to synergistic effects of ingredients such as todextrose-N, acesulfame-K and sherex 302 .

8. Vanilla and strawberry flavorings were not strong enough to cover the off-flavor developed.

9. Cocoa powder produced a flavor which was ideal for the type of product developed.

10. The final formula developed resulted in a ommercially comparable chocolate frozen dessert, with 95 calories per 100 grams.

11. This new chocolate frozen dessert product constituted a $60 \%$ calorie reduction, compared to the 241 calories per 100 grams of the base vanilla ice cream initially utilized.

\section{RECOMMENDATIONS FOR FURTHER RESEARCH.}

1. Efforts should be made to pin-point the source of the off-flavor developed at the fourth step of this research. 2. Develop different flavors, that could cover the pff-flavor, by adding ingredients such as fresh and/or prepared fruits, nut meats, other flavorings and pombinations of the above.

3. Introduce live culture to the formula developed and 
try to improve flavor and texture, by utilizing "frozen yogurt" technology. 


\section{REFERENCES}

A.O.A.C. 1980a. Nitrogen: Macro Kjeldal Method. In: nofficial Methods of Analysis of the Official Analytical Chemists". 13th ed. W. Horwitz (Ed.). Washington, DC.

A.O.A.C. 1980 b. Total Solids for Dairy Products. In: nofficial Methods of Analysis of the Official Analytical Chemists". 13th ed. W.Horwitz (Ed.). Washington, DC.

Arbuckle W.S. 1986. "Ice cream." 4th ed. Avi Publishing Co., Westport, CT.

Beckman, 1982. Instruction Manual. Models HIC-1 \& HIC-2. Beckman Industries, Inc., Cedar Grove, NJ. Bowen W.H. 1984. Role of sugars and other sweeteners in dental caries. In: "Aspertame: physiology and biochemistry". Marcel Dekker, New York, N.Y.

Bowes A.and Church H.N. 1985. "Food Values of Portions Commonly Used". 14th ed. J.B. Lippincoff Co., Philadelphia.

Caliendo M.A. 1987. "Nutrition and preventive health care". Macmillan Press. NY. 
Consumer Reports, 1989. "Ice cream bars for big kids". Consumer Reports. August.

crede B. 1985. "Why lactaid: the problem with milk and answers". Lactaid Co., Pleasantville, NJ.

Dahlqvist A. 1984. Carbohydrates. In: "Present knowledge in nutrition". 5th ed. The Nutrition Foundation, Washington, D.C.

DeAngelis, M.A. 1979. The development and use of a lactase capsule to alleviate the characteristic symptoms of lactose intolerance. M.S. Thesis, University of Rhode Island, Kingston, R.I.

Elliott R. 1988. "Trends in Industry". Dairy Field. $171: 12,10-12$

Fennema O.R. 1985. "Food Chemistry". 2nd ed. Marcel Dekker, New York, N.Y.

I.I.C.A. 1988. The Latest Scoop. International Ice Cream Association. Washington, DC.

Klis B.J. 1986b. "Sweetners". Food Technol. 40(1):112-130.

Hendley B.G. and Seymour V. 1988. Markets for Low Calorie Foods. Ch.1. In: "Low calorie products". Brich G.G. and Lindley M.G. (Ed.), p.1. Elsevier Applied Science, New York, N.Y. 
Leeder J.G. 1981. "Ice cream short cources manual". Cook College, Rutgers, NY.

M.I.F. 1959. "Laboratory Manual. Methods of Analysis of Milk and its Products". Milk Industry Foundation. washington, DC.

Kedallion Laboratories, 1986. "Non-nutritive sweetners: A rocky road to sweetness". Medallion Lab. Analytical Progress. Vol.3, No.1, Feb. Termelstein N.H. 1989. "Low-Calorie Foods". Food Technology, 43(4):113-125.

Microlife Inc., 1989. "Sherex 302. Product Information". Microlife-mpi, Inc., Sarasota, FL. Wurphy S. 1986. Sugar free low lactose ice cream. M.S. thesis, University of Rhode Island, Kingston. N.I.H. 1987. "Consumers development statement on health implications of obesity". Vol.5, No 9, National Institute of Health, Bethesda, MD. Skinner S. and Martems R. 1987. "The milk sugar dilema: living with lactose intolerance". Medi-ed Press, East Lancing, MI .

U.S.D.A.. 1987. Dairy Situation and Outlook Report. U.S.D.A. Economic Research Service. DS-412, Washington, DC. 
Walstra P. and Jenness R. 1984. "Dairy chemistry and physics". John Wiley and Sons. New York, N.Y. wittinger S.A. and Smith D.E. 1986. "Effect of Sweeteners and Stabilizers on Selected Sensory Attributes and self Life of Ice Cream". J. of Food Science $51(6): 1463-1466$. 


\section{APPENDIX "A"}

Sensory Evaluation Scoring card.

$-48-$ 
National lce Cream Retailers Association

ICE CREAM CLINIC SCORE CARD

Don.

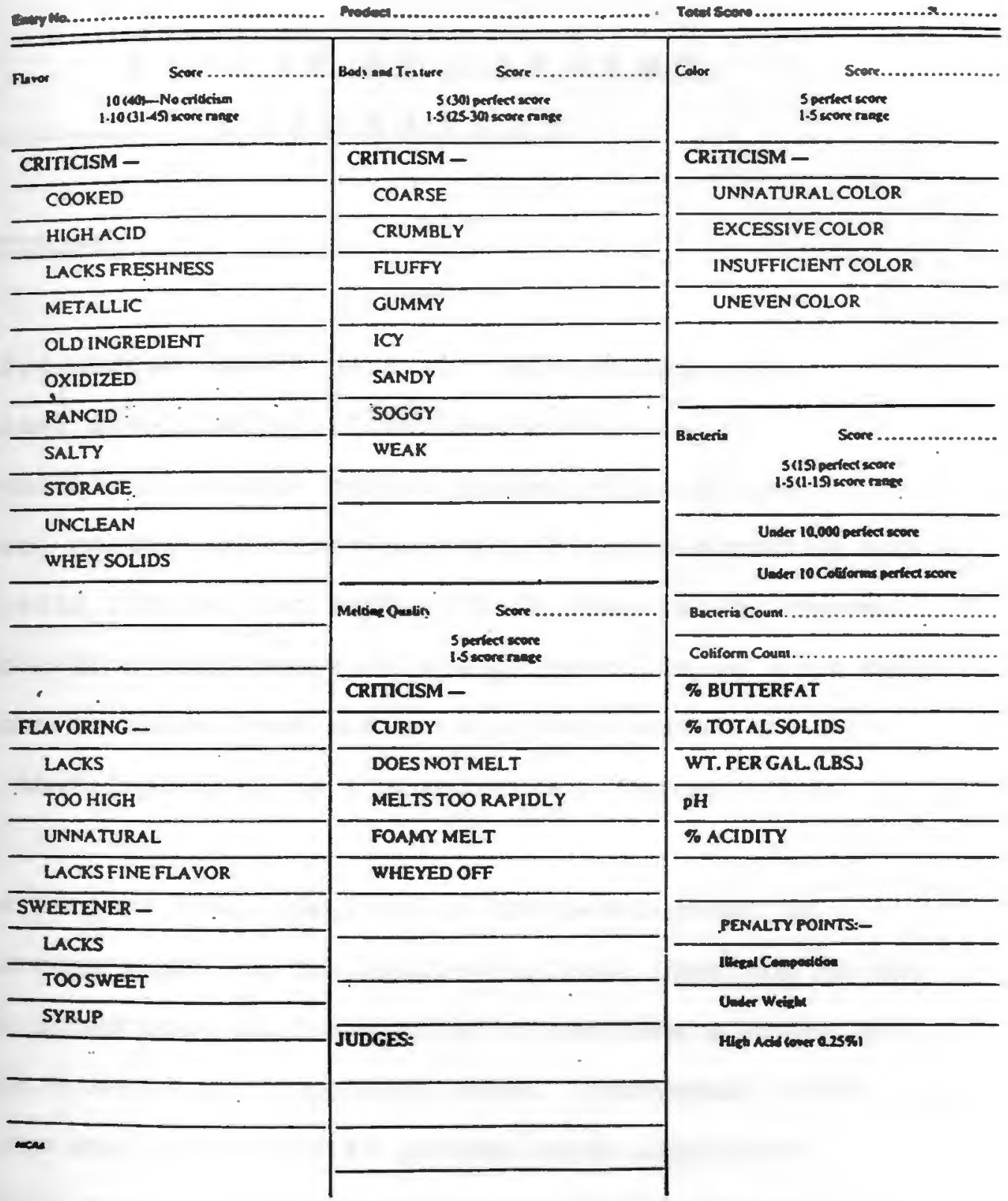


POLYDEXTROSE.

Polydextrose (see Figure 1) - a patented food Ingredient developed by Pfizer Research - is a water-soluble, randomly bonded condensation polymer of dextrose, containing minor amounts of bound sorbitol and citric acid (Pfizer Inc,1985). It is prepared by thermal polymerization of glucose in the presence of an acid that functions as a catalyst and a relatively small amount of polyol that functions as a plasticizer (Torces et.al., 1981).

The project that resulted in the development of Polydextrose began in the middle sixties, when due to the general acceptance of the synthetic sweeteners there was a need for a replacement bulking agent (Anonymous, 1984). The objective was a low calorie product with high water solubility and little or no color or flavor, which could provide the bulk and mouthfeel of sugar without sweeteness 
(Allingam, 1982).

It was Dr H.H. Rennhard, working for Pfizer Central Research Laboratories, the one who discovered polydextrose, after having explored a series of polysaccharides for their potential as reduced calorie bulking agents (Freeman, 1982; Beereboom, 1979).

Polydextrose is available in three forms: i) plydextrose, an amorphous, white to light tan powder, ii) plydextrose-N, a light colored $70 \%$ aqueous solution of polydextrose, neutralized with potassium hydroxide (Pfizer Inc,1985; Dartey et al., 1987, Murray, 1988), and iii) Type-K polydextrose, a dry blend, formulated with potassium bicarbonate so as to provide the same $\mathrm{pH}(2.5$ to 3.5$)$ as polydextrose-N solution when dissolved in water (Murray, 1988). Aqueous solutions can be easily prepared from the powder forms; viscosity of such solutions is somewhat greater than that of sucrose solutions of equal concentrations (Smiles, 1982).

Polydextrose has no sweetness. Thus it can contribute to improved mouthfeel and texture without adding excess sweetness. This provides greater formulation flexibility and freedom (Beereboom, 1979).

Various studies have shown that the polymer of polydextrose contains all possible types of glycoside bondings between glucose units. It is this random bonding 
FOIYIEXTFOSE CHEMICAL BONZINE
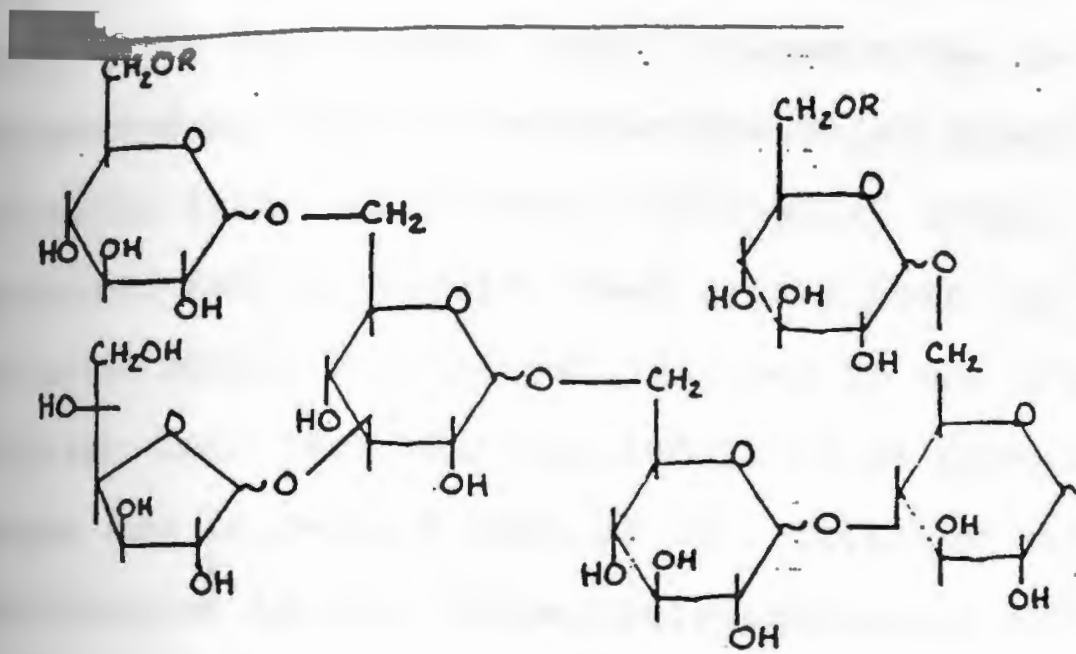
$R=$ Hydrogen
Glucose.
Sorbitol
Citric Acid
Polydextrose
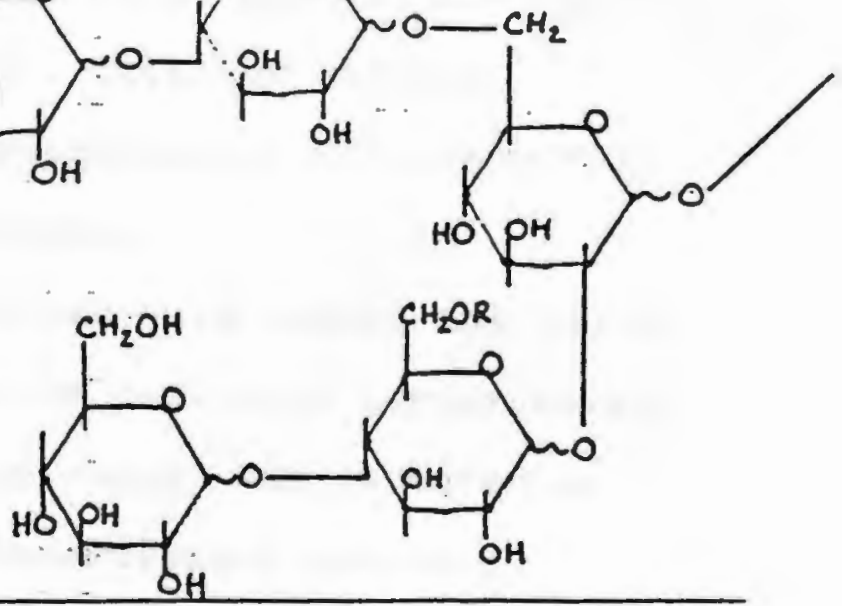

Pfizer polydextrose for the market that's shaping up. Pfizer. Inc., Chemical division. New York. i985. 
that is primarily responsible for the resistance of the polymer to enzymatic attack (Beereboom, 1979). Enzymes find it difficult to hydrolyze carbohydrate molecules of such complexity (Allinghem, 1982). Polydextrose is partially fermented by fecal microorganisms which produce some volatile fatty acids (VFA) (Allingham, 1982). The VFA are absorbed and calorically used by the host. In man, the caloric utilization of polydextrose is one calorie per gram (Pfizer Inc, 1985; Murray, 1988), or 25 percent that of sugar and 11 percent that of fat. This low caloric tilization is what allows polydextrose to significantlly reduce the caloric density of foods.

All three types of polydextrose were tested and found stable over a 90-day investigative period at temperatures up to $60^{\circ} \mathrm{C}$. The only significant change was detected at elevated temperatures where polydextrose-N showed a darkening in color (Murray, 1988).

Polydextrose is amorphous and melts above $130^{\circ} \mathrm{C}$. When polydextrose cools down it produces a clear glass, similar to hard confectionery. Unlike sugar, polydextrose will not crystallize (Murray, 1988).

Polydextrose acts as both bulking and bodying agent. As bulking agent, it contributes solids to maintain palatability and textural properties. As bodying agent, it improves mouthfeel and viscosity qualities (Murray, 1988). 
polydextrose has been proven safe to humans by many ricological studies performed in both animals and humans. These studies showed that nothing indicates any hazard to human health under the intended conditions of. use for plydextrose (Torces et al., 1981; Beereboom, 1979). Tests on Type II diebetics have shown that polydextrose does not Agnificantly affect blood glucose or insulin levels(Murray, 1988). Consequently, this product can contribute to the new dietary recomendations of low fat and sugar intakes, by being used as a sugar and/or fat substitute in food formulations (Murray, 1988). Also, other tests have indicated that neutralized polydextrose does not promote tooth decay (Murray, 1988). If large quantities of polydextrose are consumed, laxative effects will result due to fermentative action by the microbial metabolites produced in the lower intestine (Torces et al., 1981, Wurray, 1988). Clinical studies resulted in a mean laxative threshold dosage of $90 \mathrm{~g} /$ day (Beereboom, 1979). If a product has more than 15 grams per serving, it must carry the statement "sensitive individuals may experience a laxative effect from excessive consumption of this product" ermelstein, 1989).

Polydextrose has been approved by FDA in 1985 as a food additive (21 CFR 172.841) for use only in the following (Pfizer Inc, 1985) : 
1. Baked goods and baking mixes.

2. chewing gum.

3. Confections and frostings.

4. Dressings for salads.

5. Frozen dairy desserts and mixes.

6. Gelatines, puddings and fillings.

7. Hard candy.

8. Soft candy. 


\section{ACBOLFEME $-\mathrm{K}$}

on July 27, 1988, Hoechst Celanese Corporation, somerville, NJ, received approval from FDA for the use of a new non-caloric sweetener in certain foods (Anonymous, 1988). This sweetener, Acesulfame-K (Fig. 2), otherwise known as sunette ${ }^{\mathrm{TM}}$, is now commercially available under the name "Sweet one".

Acesulfame- $\mathrm{K}$ was approved for use in dry beverage mixes, instant coffee and tea, table-top sweeteners and as ingredient in chewing gum, puddings, gelatins and dairy product analogs (Anonymous, 1988; FDA, 1988).

Discovered by Dr. Karl Clauss in 1967 (while he was conducting basic research to develop new materials), acesulfame-K or acesulfame potassium, is the potassium salt of the cyclic sulfanomide:

6-methyl-1, 2,3-oxathiozine-4 (3H) -1,2,2-dioxide (Anonymous, 1988; FDA, 1988).

Acesulfame- $K$ is in a white crystalline form and it is odorless. It is 200 times sweeter than sucrose and has a clean pleasant taste at low levels of use with no unpleasant aftertaste (Medallion Lab, 1986; Murray, 1988). It can be easily dissolved in water. The solubility of peesulfame-K is high; even at room temperature and rises 
sharply with increased temperatures (Murray, 1988; Klis B.J., 1986). A $20 \%$ solution can readily be prepared at

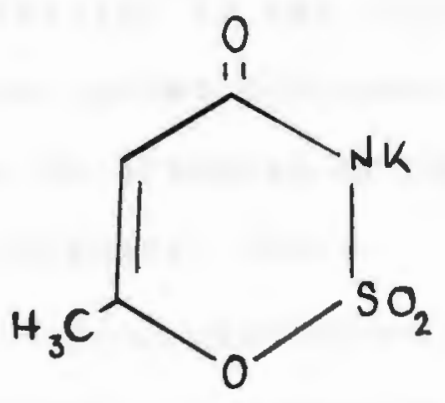

Fig. 2 Structural formula of Acesulfame-K

(Anonymous, 1988).

$20^{\circ} \mathrm{C}$. Solubility in ethanol is low but easily enhanced with the addition of water ( $\mathrm{Kl}$ is B.J., 1986).

Acesulfame-K exhibits no distinct melting point (degradation typicaly occurs at $225^{\circ} \mathrm{C}$, temperatures much higher than those normaly found in foods even during Mgh-temperature processing) (Murray, 1988; Klis B.J., 1986).

Acesulfame- $\mathrm{K}$ is not metabolized by the body and is excreted unchanged (Microlife Inc, 1989; Lipinski, 1985). In human studies using ${ }^{14} \mathrm{C}$-marked acesulfame-K, over $99 \%$ of the dose was excreted in urine and less than $1 \%$ in feeces (Murray, 1988). From farmacocinetic calculations it was concluded that no accumulation of acesulfame-K in the 
body seems possible even after repeted ingestions within short periods (Murray, 1988).

Exceptional stability in the crystalline state is reported for samples stored for about ten years at ambient temperature. It is not affected by pH values of 3 or higher (Klis B.J., 1986; Lipinski, 1985).

Like other artificial sweeteners, acesulfame-K has come through pharmacological and toxicological tests with a clean slate (Dermot, 1983). It has been tested in more than fifty studies conducted without any negative findings (Kurray, '1988; Anonymous, 1988; Dermot, 1983). Acesulfame-K was fed to diabetic rats for a prolonged period in order to study its influence on a diabetic organism. In this study no negative effects were observed (Murray, 1988).

The A.D.I. (acceptable daily intake) set by FDA is $15 \mathrm{mg} / \mathrm{kg}$ of body weight (Anonymous, 1988c). A lower A.D.I. has been commissioned by WHO/FAO at $9 \mathrm{mg} / \mathrm{kg}$ body weight (Lipinski, 1985).

According to the supplier's information (Hoechst, 1988), there are quite a few commercial products in Europe entaining acesulfame-K, whereas in the Us there are none listed, basically due to the very recent approval by FDA (Hoechst, 1988). 
QIBRE 302.

In response to all of the new products and the recent trends in the market, Microlife-mpi has developed a spectrum of stabilizers, called Sherex, each of which attains a specific product profile.

Sherex 302 is a stabilizer designed for use in hard serve frozen dairy products like ice cream and ice milk. A usage rate from 0.46 to $0.90 \%$ is recommended by the manufacturer (Microlife Inc, 1989). According to the technical information supplied with the product, sherex 302 gives excellent stabilization to low-fat or non-fat frozen desserts, with heat shock protection and extra creamy mouthfeel (Anonymous; 1989b).

Sherex 302 is a white, odorless powder, which disperses rapidly. It contains a combination of not only stabilizers but also emulsifiers as shown below in the ingredients list (Anonymous, 1989b) : Microcrystaline cellulose (MCC), monoand diglycerides, dextrose, guar gum, sodium Prboxymethylcellulose (CMC), calcium sulfate, polysorbate 80 and carrageenan.

Microcrystaline cellulose (MCC) acts as a general mulsifying agent (Arbuckle, 1986). Mono- and diglycerides are also emulsifiers. Monoglycerides improve fat dispersion 
and whipping ability (Arbuckle, 1986; Fennema, 1985). piglycerides are more effective in producing dryness and stiffness and increasing the melting time (Arbuckle, 1986; Fennema, 1985). Dextrose, a refined corn sugar, is cuficiently effective in lowering the water activity while being tolerable organoleptically (Fennema, 1985).

Guar gum is a complex carbohydrate used as a stabilizer. It is readily soluble in cold solutions and gives very good results in combination with CMC and carrageenan for products undergoing HTST or continuous pasteurization (Arbuckle, 1986). Sodium carboxymethylcellulose (CMC), is a stabilizer easily dissolved in the mix (Arbuckle, 1986). Its water binding capacity makes it useful in ice cream and other frozen desserts, in which it retards ice crystal growth (Fennema, 1985). CMC is used in dietetic foods to provide the bulk, body and mouth feel that would normally be contributed by sucrose (Fennema, 1985). Studies have shown that combinations of CMC with guar gum and carrageenan have been ouccessfully used in ice cream, improving whipping properties (Arbuckle, 1986). Calsium sulfate is listed under "stabilizing and thickening agents" (Arbuckle, 1986). It increases the acidity of the mix, produces a dry, stiff ice cream and reduces the melting rate (Arbuckle, 1986). It has little effects on other properties of the mix or 
Iinished product (Arbuckle, 1986).

polysorbate 80 (polyoxyethylene sorbitan monooleate), is one of the two synthetic emulsifiers that are legal for use in ice cream (Arbuckle, 1986). It enhances the whipping properties of the $\mathrm{mix}$ and improves the body and texture of the finished product (Arbuckle, 1986). Carrageenan is a stabilizing agent, extracted from the seaweed carrageen. It can be added to the mix as easily as gelatin and aids in the prevention of wheying off (Arbuckle, 1986; Fennema, 1985).

OBESITY

Obesity, generally described as the storage of excessive amounts of fat, is a major health problem in the U.S. Affecting about 34 million adults ages from 20 to 74 , obesity ranks amongst the most prevalent diet related problems in this country (The Surgeon General's Report, 1988).

No ideal definition for obesity currently exists. The most commonly used methods estimate body fat as a percentage of total body weight (underwater weighing), establish an index of body fat level (skinfold thickness or ist-to-hip circumference measurments), compare weight or 
height measurements (height and weight tables), or compute an index of body weight as a function of height (BMI, body mass index $=\mathrm{kg} / \mathrm{m}^{2}$ for men or $\mathrm{kg} / \mathrm{m}^{1 / 2}$ for women) in reference to population standards (The Surgeon General's Report, 1988; Mermelstein, 1989).

Obesity is a health risk associated with a number of diseases. It may predispose an individual to pperlipidemia, hypercholesterolemia, diabetes (Hermelstein, 1989). Hypertention, digestive diseases, heart and cardiovascular diseases and cancer are also directly correlated to obesity (The Surgeon General's Report, 1988; Murray, 1988).

There are numerous studies done to investigate the consequences of obesity on longevity, the most important being the Build and Blood Pressure Studies of 1959 and 1979, the American Cancer Society Study, the Framingham 30-year follow-up study, the seven countries study (The Surgeon General's Report, 1988, Mermelstein, 1989; Murray, 1988). All of these studies have shown clearly and undisputedly that the risk of mortality increases Agnificantly for obese people, and concluded that the obese tend to die young (Murray, 1988; The Surgeon General's Report, 1988; Finer, 1988)

The etiology of obesity is complex, related to Hestyle, heredity, aquired physical and physiological 
disabilities, cultural patterns and personality (The surgeon General's Report, 1988; Finer, 1988 ; Mermelstein, 1989). Accordingly, treatments for obesity are complicated

- and not unique. The one common objective shared by all treatments is the loss of weight. In order to lose weight, one must decrease caloric intake, increase caloric expediture, or do both (Finer, 1988). It has been proven that weight loss reduces risks in the obese (The surgeon General's Report, 1988).

The Surgeon General's report (1987) clearly states that Americans in general would benefit not only from a Iifestyle that includes more physical activity but also from a diet containing fewer calories. It also urges the industry to continue developing low calorie food products.

\section{DIABETES MELLITUS}

Diabetes is characterized by metabolic abnormalities of which the most evident is hyperglycemia and elevated concentrations of blood glucose (Metcalfe, 1988, The Surgeon General's Report, 1988). It is also characterized by long term complications involving multiple organs, especialy the eyes, kidney, nerves and blood vessels (Arky, 
1984, Metcalfe, 1988). These complications result from a deficiency of the hormone insulin, or a reduction of the effectiveness of insulin. There are two major forms of diabetes mellitus: Type-I or insulin-dependent, (IDD) and Type-II or noninsulin-dependent, (NIDD) (Metcalfe, 1988, The Surgeon General's Report, 1988). In Type-I diabetes, there is need for exogenous replacement of insulin which is necessary for the metabolism of glucose. In Type-II there is no such need (The Surgeon General's Report, 1988).

The substantial impact of diabetes on the health of Americans has been documented extensively. Eleven million people are estimated to have diabetes (The Surgeon General's Report, 1988). Type-I diabetes in most cases appears before the age of 40 . According to the 1988 Surgeon General's Report, diabetes is directly responsible for nearly 36,000 deaths each year in the U.S., making it the seventh leading cause of death in this country. It also contributes to nearly 95,000 additional deaths per year, $75 \%$ of which are due to cardiovascular complications. Other complications associated with the progression of diabetes include kidney disease, angiopathy, congestive heart failure and stroke (Arky, 1984; Metcalfe, 1988). Also, petinopathy, which for the diabetic is a common cause of blindness (Arky, 1984; Caliendo, 1987). In addition to all above complications, diabetes is responsible for about $45 \%$ 
of all nontraumatic leg and foot amputations in the U.S. (The Surgeon General's Report, 1988; Caliendo, 1987).

primarily, diabetes mellitus is believed to be a genetic disease. In diabetes the body is unable to regulate the metabolism of food. The genetic pattern has been related to certain antigens which appear to pass on a vredisposition to diabetes rather than the disease itself (Arky, 1984; Metcalfe, 1988). Development of the disease then seems to be determined by varying environmental as well as genetic factors (Arky, 1984).

currently, there is no cure for diabetes. Prevention of Type-II diabetes is possible. Estimates suggest that new cases of diabetes could be lowered by half by preventing obesity in adults (The Surgeon General's Report, 1988; Metcalfe, 1988). Successful treatment of the disease is complex and depends on cooperative effords of health professionals as well as the patient. No diabetic patient can be successfully treated without following a diet regiment (Metcalfe, 1988). The individual must know what foods to select. A diet containing 50 - 60\% of total energy as cho is now recommended for individuals with diabetes (The Surgeon General's Report, 1988). Also, in order to reduce the risk of heart coronary disease, a diet low in fat, saturated fat, and cholesterol is suggested (Arky, 1984, The Surgeon General's Report, 1988). The majority of 
those involved in diabetic managment and education feel the case for energy-reduced diets in the managment of diabetics has been proven (Metcalfe, 1988). The practical uplementation of advice that can achieve energy reduction is what must concern the diabetic, the professional advisers, the food industry and the legislative body (Netcalfe, 1988).

Alternative nutritive sweeteners like fructose or sorbitol may be used without direct impact on diabetics but they do contribute calories. On the other hand, non-nutritive sweeteners (aspartame, saccharine, sunette etc.), provide no calories on relation to their sweetness. The American Diabetes Association's current position is that both nutritive and non-nutritive alternative sweeteners are acceptable in the managment of diabetics (The Surgeon General's Report, 1988).

\section{IACTOSE INTOLERANCE}

Chemically, lactose is a disaccharide, consisting of one residue each of D-glucose and D-galactose (Lehninger, 1982; Walstra, 1984). Lactose, is the natural sweetener of milk, where it is found in levels of about 58. (Walstra et al., 1984). 
Like other disaccharides, lactose must be hydrolyzed before it can be transported through the intestinal membranes. In order to be utilized by the human body lactose has to be hydrolyzed to its monosaccharite components glucose and galactose (Walstra et al. 1984). This hydrolysis takes place in the brush border mucosal cells of the intestine, where the enzyme $\mathbb{A}$-galactosidase (lactase) is found (Walstra, 1984; Houts, 1988).

In lactose intolerant individuals this enzyme is present in low concentrations or it is absent. Lack of the enzyme lactase results in lactose passing into the large intestine where it is fermented by bacteria, releasing hydrogen (Scrimshaw et al., 1988 and Houts, 1988). Also, lactose present in the large intestine holds water which would otherwise be drawn out osmotically. Thus, digestive-track distress,abnormal cramps, bloating, flatulance and/or diarrhea may result (Walstra et al., $1984)$.

Generally, literature suggests that $30-95 \%$ of the lactose intolerant individuals experience the symptoms tollowing ingestions of about 15 to $50 \mathrm{gm}$ of lactose (Walstra et al., 1984; Scrimshaw et al., 1988).

Population groups with low percentage of lactose Intolerance $(0-30 \%)$ are generally found in geographic areas where people are known to have the longest tradition 
of dairying, these areas being North-West Europe, and some pockets of the Mediterranean and Near East countries, Africa and the Indian subcontinent (Houts, 1988). On the other hand, population groups displaying high proportions of lactose intolerance $(60-100 \%)$ are found in areas where dairying or adult milk usage has never, until recently, been a part of the culture. White Americans have been found to have lactose intolerance rates of 6 to 25\%, while Black Americans have intolerance rates of 47 to $74 \%$ and American Indians and Eskimos $75 \%$ (Houts, 1988).

Lactose intolerance raises significant questions and problems such as the greater risk of malnourishment for low income groups which also show higher prevelence of the disease (Houts, 1988). Also, the question whether lactose absorption is necessary for utilization of the nutrients in milk (such as calcium) must be studied (Houts, 1988). In addition, the question of whether or not persons beyond the young-adult stage can become genetic lactose intolerant must be examined (Houts, 1988). If this is possible, then lactose intolerance will prevale - especially since the median age in the U.S. is increasing (Houts, 1988). Ponsequently milk may not be considered a reliable source of nutrients for a large portion of the population, a fact that raises new public health concern (Houts, 1988). In an ordinary diet, it is difficult for someone to 
avoid lactose in unaltered forms, even if consumption of fresh dairy products is eliminated. Cooking the milk does not convert lactose to glucose or lactic acid; cream soups, puddings, cream pies and custards are not usually lactose free foods (Houts, 1988). In order to obtain a diet that would be discomfort-free yet nutritious, the lactose intolerant individual should consider options such as determining the threshold for the symptoms to occur and limit consumption of lactose to lower levels. Consumption of fermented foods is also suggested. During fermentation, 30-40\% of the lactose is broken down and thus the lactose content is reduced (Scrimshaw et al., 1988). Products such as yoghurt and some natural cheeses (naturaily aged cheddar and Swiss cheeses) are either low in lactose or have inherent lactase activity (Houts, 1988; Martini et al., 1987; Scrimshaw et al., 1988). Another option is to add lactase to the fluid milk prior to its use. This process "predigests" major part of the lactose in milk making the milk product easily digestible for the lactase deficient person. Some of the suggestions made to the industry are to use lactose-reduced dairy ingredients in their processed foods and to manufacture a greater variety of lactosereduced dairy products for daily consumption (Houts, 1988). 
TCE CREAM AND OTHER FROZEY DESEERTS.

Ice cream is a pasteurized frozen dairy product made by freezing while agitating a mix of milk products, tabilizers, emulsifiers, flavors and other ingredients (Arbuckle, 1986). It is a complex food system where we have substances in true solution, others in colloidal suspension and the fat as an emulsion (Sommer, 1951). In true solution are, the milk salts, lactose, sucrose. In colloidal suspension there are, the milk proteins, gelatin, egg proteins (if eggs are used) (Sommer, 1951). Ice cream is a tasty and nutritious food. An average $100 \mathrm{gm}$ serving supplies approximately 200 calories, $23.9 \mathrm{gm} \mathrm{CHO,} 10.8 \mathrm{gm}$ fat and $3.6 \mathrm{gm}$ of protein (Arbuckle, 1986).

Ice cream, among all other desserts available, is the one served more often in hotels and restaurants (Arbuckle, 1986; Leeder, 1981). It is very popular, especially in the United states, where along with all ice cream related products, production during 1987 reached a peak of 1.4 billion gallons. This figure puts the U.S. in first place world-wide for production of ice cream (Arbuckle, 1986; I.I.C.A., 1988).

Ever since the time when ice cream proved its popularity, other products related to ice cream have been 
meroduced in the market. At the begining of the century, because of this development, new classifications for the ice cream products were needed (Arbuckle, 1986). Criteria for classification which were tried varied from whether the product did or did not have eggs, to the shape of the product and the decorations (Arbuckle, 1986).

In the last 10 to 15 years, an excess of ice cream related products have flooded the market. Products include ice milk, sherbets, mellorine, ices, frozen yogurt and others. These products constitute a significant part of the ice cream industry. In 1987, $66 \%$ of the total production was ice cream products (hard and soft), while ice cream related products made up the remaining $34 \%$. (I.I.C.A., 1988).

Federal standards for frozen desserts were first issued in 1960 by the U.S. Department of Health, Education and Walfare, Food and Drug Administration (FDA) under the Federal Food, Drug, and Cosmetic Act, Part 20, Title 21, Code of Federal Regulations (Arbuckle, 1986). In 1974, the identity standards were rewritten to reflect changes in the industry (new standards were issued as Part 135). These standards were published in the 1982 Code of Federal Degulations. Under these standards, ice cream must have at least $10.0 \%$ milk fat, not less than $10.0 \%$ MSNF and not less than 1.6 pounds of total solids to the gallon (Arbuckle, 
1986, Code of Federal Regulations, 1982). Ice cream must weigh not less than 4.5 pounds to the gallon. Microbial counts, acidity, along with optional dairy ingredients, fruits, flavors and other possible constituents are also covered under these standards (Arbuckle, 1986, Code of Federal Regulations, 1982). Any product that does not satisfy these standards, can not be called ice cream. There are standards for ice cream related products such as sherbets or ice milk, but there are also products that have been introduced in the market recently and do not clearly belong to any of these categories, (the most aignificant being frozen yogurt). These products fall in the category generaly described as "ice cream related products", or "frozen dairy desserts". Legislation that will cover all the new products is under review by the FDA since there is considerable pressure from the industry for standards that will ensure high quality products, and will protect the consummers.

The basic mix for the manufacture of ice cream is largely cream and other milk products, sweeteners, flavors and small amounts of functional ingredients such as stabilizers and emulsifiers (Arbuckle, 1986). All ingredients of the mix are carefully blended in proper proportions in a mixing tank. The mix then goes to a pasteurizer where it is heated and held at a predetermined 
temperature for a specific period of time, (the most common combination being HTST, at $79.5^{\circ} \mathrm{C}$ for 25 seconds) (Arbuckle, 1986; I.I.C.A., 1988). The mix is then homogenized under pressure from 2,000 to 2,500 psi (Arbuckle, 1986; I.I.C.A., 1988). After homogenization, the hot mix is quickly cooled to about $4^{\circ} \mathrm{C}$. Next, freezing of the mix is accomplished; while ice cream is being frozen, blades -commonly known as "dashers"- whip and aerate the product. The air uniformly whipped into the product as small air cells, is necessary to prevent ice cream from being too dense, too hard and too cold (Potter, 1978; I.I.C.A., 1988). The air, in the form of small air cells, is dispersed through the water-fat emulsion, acting as an insulator (Arbuckle, 1986). Whipping during freezing causes increases in volume, known as overrun. The usual range of overrun in ice cream is from 70 to $100 \%$ (Arbuckle, 1986; Potter, 1978). (One liter of mix makes two liters of frozen ice cream with $100 \%$ overrun). Following the freezing process, the packages are filled, and immediately placed in the "hardening room" where temperatures below $-20^{\circ} \mathrm{C}$ further harden the ice cream.

The quality of the individual ingredients used for the production of ice cream is important in determining the quality of the final product. As discussed below, each ingredient or processing step, contributes in a very 
epecific and unique way to the characteristics of the final product. (Table 15 summarizes the advantages and limitations of various ice cream constituents).

\section{ilkfat.}

Milkfat, an ingredient of major importance to ice cream, is supplied by milk or cream (Arbuckle, 1986; charley, 1982). The correct percentage of milkfat in the mix is essential not only to the quality of the final product, but also in meeting the legal standards, which require at least a $10 \%$ butterfat content (Arbuckle, 1986). Butterfat does not lower the freezing point of the mix; but it does increase the body of the final product and gives a smooth texture (Arbuckle, 1986). By forming a mechanical barrier around ice crystals, butterfat affects ice crystal formation, so that more but smaller crystals are formed (Arbuckle, 1986; Charley, 1982). Milkfat enhances the flavor of ice cream. This is thought to be due to the fact that fat particles tend to concentrate toward the surface of air cells during the freezing process (Arbuckle, 1986). Products with higher fat content will seem finer in texture due to lubricating effect of the fat droplets on the ice crystals (Charley, 1982). Fat content raises the caloric value and the price of the product, both of which may be 
ADVANTAGES AND LIMITATIONS OF VARIOUS ICE CREAM CONSTITUENIS

\begin{tabular}{|c|c|c|}
\hline Constituent & Advantages & Limitations \\
\hline Milk fat & $\begin{array}{l}\text { Increases the richness of the flavor } \\
\text { Produces a characteristic smooth } \\
\text { texture } \\
\text { Helps give body to the ice cream }\end{array}$ & $\begin{array}{l}\text { Cost } \\
\text { Fat slightly hinders, rather than } \\
\text { improves, whipping } \\
\text { High fat content may limit the } \\
\text { amount of ice cream consumed } \\
\text { High caloric value. }\end{array}$ \\
\hline MSNF & $\begin{array}{l}\text { Improves the texture } \\
\text { Helps to give body } \\
\text { A higher overrun without snowy } \\
\text { or flaky texture } \\
\text { A comparatively cheap source of } \\
\text { solids }\end{array}$ & $\begin{array}{l}\text { A high percentage causes } \\
\text { sandiness } \\
\text { The condensed-milk flavor may be } \\
\text { objectionable } \\
\text { May cause salty or cooked flavor }\end{array}$ \\
\hline Sugar & $\begin{array}{l}\text { Usually is the cheapest source of } \\
\text { solids } \\
\text { Improves the texture } \\
\text { Enhances the flavor }\end{array}$ & $\begin{array}{l}\text { Excessive sweetness } \\
\text { Lowers whipping ability } \\
\text { Longer freezing time required } \\
\text { and ice cream requires } \\
\text { a lower temperature } \\
\text { for proper hardening }\end{array}$ \\
\hline Stabilizers & $\begin{array}{l}\text { Very effective in smoothing the } \\
\text { texture } \\
\text { Very effective in giving body to } \\
\text { the product }\end{array}$ & $\begin{array}{l}\text { Excess body and melting resis- } \\
\text { tance }\end{array}$ \\
\hline $\begin{array}{l}\text { Egg yolk } \\
\text { solids }\end{array}$ & $\begin{array}{l}\text { Very effective in improving whip- } \\
\text { ping ability } \\
\text { Produces a smooth texture } \\
\text { Flavor }\end{array}$ & $\begin{array}{l}\text { Excessive amounts may produce } \\
\text { faminess on melting } \\
\text { Egg flavor not relished by some } \\
\text { consumers } \\
\text { Cost }\end{array}$ \\
\hline TS & $\begin{array}{l}\text { Smoother texture } \\
\text { Better body } \\
\text { More nutritious } \\
\text { Ice cream not as cold }\end{array}$ & $\begin{array}{l}\text { Heavy, soggy or pasty body } \\
\text { Cooling effect not high enough }\end{array}$ \\
\hline Flavor & Increases acceptability & $\begin{array}{l}\text { Harsh flavors less desirable } \\
\text { Intense flavors quickly satisfy } \\
\text { desire }\end{array}$ \\
\hline Color & $\begin{array}{l}\text { Improves attractiveness } \\
\text { Aids in identifying flavor }\end{array}$ & \\
\hline
\end{tabular}


limiting factors to consumption. Also, the higher the fat content, the easier it is for the fat globules to churn during processing and give detectible butter chips (Axbuckle, 1986).

\section{Hilk Solids Non Fat.}

Milk solids non fat (MSNF), are solids of skim milk. MSNF consists of $55.5 \%$ lactose, $36.7 \%$ protein and $7.8 \%$ minerals (Arbuckle, 1986). It does not add much to the flavor of ice cream but it does provide body and enhances the palatability of the final product. MSNF increases the viscosity of the mix, lowers the freezing point, and helps to achieve a higher overrun without snowy or flaky texture (Charley, 1982). MSNF is a low-cost way to increase the body and total solids (T.S.) of ice cream but care must be taken as too high a percentage of MSNF causes "sandiness" and may give the product a "condensed milk" flavor (Arbuckle, 1986; Charley, 1982)

\section{Sweeteners.}

The sugar introduced into the ice cream mix enhances the taste, texture and flavor of the product. Sugar increases ice cream's acceptability not only by making the 
product sweeter but also by enhancing the pleasing creamy flavor (Arbuckle, 1986). The presence of sugar in the mix affects ice crystal formation in two ways. First, it lowers the freezing point, thus requiring lower temperatures for freezing and hardening (Charley, 1982). Secondly, sugar keeps the size of the ice crystals small by increasing the amount of liquid which remains unfrozen (Arbuckle, 1986; Charley, 1982). Added sugar, also increases the viscosity and the total solids of the mix (Arbuckle, 1986). Above the $16 \%$ level, sugar tends to make ice cream soggy and sticky. Also, excessive sweetness and extreme lowering of the mix's whipping ability may result from high concentrations of sweetener (Arbuckle, 1986; Charley, 1982). The sweeteners, along with fat, MSNF, stabilizers and emulsifiers, make up the total solids (T.S.) of the ice cream mix. When T.S. reach levels higher than 40 to $42 \%$, the product is more likely to be soggy and undesirably heavy (Arbuckle, 1986; Charley, 1982).

\section{Stabilizers.}

Stabilizers are used in ice cream mixes to improve mix viscosity, air incorporation, to slow down ice crystal formation, improve body and texture, melting properties, and especially to prevent a coarse and sandy texture from 
temperature fluctuations during storage (Arbuckle, 1986, Nielsen, 1984). Stabilizers are used in very small amounts and so they do not influence either the nutritional value or the flavor of the product. Stabilizers come from either animal or plant sources. When they are dispersed in water, they form a gel matrix with the available water molecules and in this way restrict the mobility of the water (Arbuckle, 1986; Nielsen, 1984). They have a high water-holding capacity, which contributes to improved body and texture of the product (Arbuckle, 1986).

The amount of stabilizer used varies from 0 to $0.5 \%$, according to its properties, the concentration of the T.S., the type of processing equipment and other factors (Arbuckle, 1986). Excessive use of stabilizers will result in undesirable melting resistence and soggy body (Arbuckle, 1986).

stabilizing substances that are permited and used in the making of ice cream are agar, sodium alginate, gelatine, guar seed gum, locust bean gum, carrageenan, CMC, and others (Arbuckle, 1986).

\section{Enulsifiers.}

These are substances which reduce the surface tension at the interface of two normaly immiscible phases, allowing 
them to mix and form an emulsion (Dziezak J, 1988).

The reason emulsifiers are used in the manufacture of ice cream are to give the product a smoother texture, stiffer body and to reduce the whipping time (Arbuckle, 1986). As the agitated freezing of the mix progresses and air is incorporated, the air cells become surrounded by an aqueous film containing dispersed milk proteins, which also contains emulsified fat and ice crystals (Charley, 1982). Some of the emulsifying agents commonly used in the ice cream industry are: lecithin, mono- and diacylglycerols, polyoxyethylene sorbitan esters, polysorbate 80 (polyoxyethylene sorbitan monooleate), fatty acids $\left(c_{10}-c_{18}\right)$, polyglycerol esters, microcrystaline cellulose (MCC) and others (Arbuckle, 1986; Fennema, 1985). The total amount of emulsifiers by weight may not exceed 0.2\%. (Arbuckle, 1986; Dziezak J, 1988). Excessive use of such substances may result in slow and foamy melting, and textural defects (Arbuckle, 1986). 


\section{A P P E I D I 8 "CH}

Mational Ice cream and Yogurt Retailers Association Project.

In order to further study frozen dessert products and to become acquainted with the commercial production and marketing of the product, the investigator undertook a special project for the National Ice Cream and Yogurt Retailers Association (N.I.C.Y.R.A.) .

This project consisted of physical (fat content, total solids, overrun, $\mathrm{pH}$, weight per volume, total plate count and coliform count), and sensory tests run on ice cream samples. The results were presented at the 1989 annual convention of N.I.C.Y.R.A. which was held in Boston, Mass.

Methods - Materials.

Members of N.I.C.Y.R.A. were asked to submit samples 2 to 3 months ahead of time, at the Food science and 
Nutrition Department of the University of Rhode Island, Kingston, RI. The letter and application are shown on next page. All equipment and material required for the completion of this project were provided by the F.S.N. Department.

Uppon arrival, all samples were numerically coded and were immediately placed in the hardening room at $-23^{\circ} \mathrm{C}$. The weight per volume for each sample was determined in two ways, as follows: a) The sample was first weighed along with its $1 / 2$ gallon container. A similar $1 / 2$ gallon container was then weighed empty, and from the diference, the gross weight of $1 / 2$ gallon product was determined. This was multiplied by 2 to give the "lb/gal" value for the sample. b) A standard $1 / 2$ cup measure, of known weight, was filled with sample and weighed. From the diference, the weight of $1 / 2$ cup sample was determined. This was multiplied by 31.997 in order to give the "lb/gal" value of the product. In case of a large discrepancy between the results of two methods, the second method was repeated and that was the number recorded.

The fat content was determined by the Pennsylvania Test, a modified Babckok test, as described by the Milk Industry Foundation (1959).

The total solids were determined according to the A.O.A.C. method (A.O.A.C., 1980b). 


\section{RULES AND POLICIES \\ FOR SUBMITTIKG ICE CREAM SAMPLES}

Send entry blank to Association Office, 1429 King Avénue, Suite 210, Columbus, Ohio 43212. HOT LATER THAN AUGUST 18, 1989.

Each sample shall consist of two (2) half-gallon packages. Samples shall consist of regular run products drawn from the freezer consecutively (samples for analysis and judging). Use plain containers so that the manufacturer may not be identified at the Clinic, manufacturer's name should appear only on the outside of the shipping container. Samples packaged in unusual or merked packaging may be easily identified, therefore, any samples submitted in other than plain half gallon containers may be rejected.

\section{OFFICIAL CONTEST FLAVORS - VANILLA - CHOCOLATE}

All samples for the Clinic must be shipped to arrive between Monday and Thursday, August 28-31, from 8:30 AM to 5:00 PM, and to contain a label: "Persons receiving and signing for package to immediately place in deep freeze or hardening room"(or a message to this effect so that package is not lying around at room temperature).

Both one-half galion cartons of each flavor entered in the clinic should be addressed to: Professor Clifford J. Cosgrove, Food Science and Nutrition Research Center, University of Rhode Island, 530 Liberty Lane, W. Ringston, RI 02892 . Telephone: $401 / 792-4021$ or $401 / 792-2467$.

Samples should be shipped BXPRESS AIR FREIGET or EXPRESS MAIL direct 1 y to the above address. Shipments should be labeled "PACRED UITH DRY ICE - HIGHLY PERISBABLE - EXPEDITE - ICE CREAM". Pack with plenty of dry ice to provide 48 hours of frozen environment. This will assure arrival of the samples in excellent condition. A suggestion when shipping jour samples by air freight, would be. to initiate shipment in the late afternoon or early evening of the day before you wish the package to arrive at its destination. Usually the freight is handled more efficiently by the airlines during the night hours.

NOTE:

You are required to file two (2) copiea of the "SHIPPER'S CERTIFICATION FOR RESTRICTED ARTICLBS" with the air freight carrier as carbon dioxide (dry ice) is identified as a restricted material. Also, the shipping carton should be marked on at least three ( 3 ) sides with the identifying marks "ORH-A".

Results of analysis and judging will be given to you by a code. The Judging of the samples will be done by a panel of trained and experienced judges in cooperation with Professor Clifford J. Cosgrove, University of Rhode Island. West Kingston, RI 02892 . 
The overrun for each sample was calculated through the "lb/gal" value and under the assumption that all mixes weighed $9.1 \mathrm{lb} / \mathrm{gl}$ before the freezing process. An example of the overrun calculation is given bellow:

$$
\begin{aligned}
\text { mix...... } & 9.11 \mathrm{~b} / \mathrm{gal} \\
\text { sample... } & 4.91 \mathrm{~b} / \mathrm{gal} \\
9.1- & 4.9 \\
\text { overrun }= & -
\end{aligned}
$$

$$
4.9
$$

An Orion Research 201 model digital pH meter equiped with an Orion 91-06 probe was used for measuring the $\mathrm{pH}$ of the samples. The instrument was calibrated at pH 4.00 and 7.00. Approximately $40 \mathrm{ml}$ of each sample were allowed to melt under room temperature and then $\mathrm{pH}$ was measured.

Both the total plate count and the coliform count were done according to Post (1983). Violet red bile agar dehydrated and plate count agar dehydrated ware used, both by DIFCo Laboratories, Detriot, Michigan.

All of the above tests were run in duplicate. In case of a significant difference between the two readings, that specific sample was run in triplicate.

Sensory evaluation was done by a panel of 13 trained and experienced judges under the supervision of Prof. Clifford C. Cosgrove, of the F.S.N. department. Sensory 
scoring was done according to the score card in appendix A. In order to evaluate the melting characteristics of the samples, one scoop of each sample was let to melt under ambient temperature in separate plate. In this way, each judge could observe the samples melting and evaluate them accordingly.

Points were added to the total sensory score (max. 25.0 points), according to bacteria count as follows:

5 points for TPC $<10,000$ and coliform $<10$.

$$
\begin{array}{llll}
4 & \text { " } & 10,000<\mathrm{TPC}<20,000 \\
3 & \text { " } & & \text { " } 20,000<\mathrm{TPC}<30,000 \\
2 & \text { " } & 30,000<\mathrm{TPC}<40,000 \\
1 & \text { " } & 40,000<\mathrm{TPC}<50,000 \\
0 & \text { " } & 50,000<\mathrm{TPC} \text { and / or coliform }>10 .
\end{array}
$$

From the points earned by sensory and bacteria count, penalty points were deducted for each illegal composition (fat<10.0\%, T.S. $<35.5 \%$ and $1 \mathrm{~b} / \mathrm{gal}<4.55$ ). Points earned and deducted penalty points made up the grand total, (max. 30.0 points), according to which each sample was ranked. Vanilla and chocolate samples were grouped separately.

\section{RESULTS AND DISCUSSION}

A total of 61 samples were recieved for analysis, of 
which 32 were vanilla and 29 were chocolate. Samples were submitted by 30 diffetent participants from 16 states and Bermuda. All samples arrived in good condition with no melting problems. Four of the samples were sent in labelled containers although the instructions indicated differently for reasons of confidenciality, as well as for unbiased sensory evaluation.

By weighing the $1 / 2$ gallon containers, we could easily determine the "lb/gal" values of the products. Since the volume of the product in the containers was not allways exactly $i / 2$ gallon, another means of calculation was required. By implying the second test (weighing $1 / 2$ cup volume), which was time consuming and strenuous, a more accurate calculation was made.

Measuring the overrun, the assumption for the weight of the mix was based on the late literature (Arbuckle 1986), where the figure of $9.1 \mathrm{lb} / \mathrm{gal}$ is the lowest average for commercial ice cream mixes. Keep in mind that $9.01 \mathrm{~b} / \mathrm{gal}$ is the lowest legal limit for an ice cream mix. The use of this figure in our calculations serves to the benefit of the contestants since for the same "lb/gal" of finished product, a heavier mix will give a higher overrun value.

All results have been tabulated and are included in the last 9 pages.

As far as fat and total solids are concerned, all 
vanilla samples were within the legal limits. On the other hand, one chocolate sample was low in fat $(9.8 \%)$ and one was low in both fat and total solids (9.5\&33.4\%).

Nine vanilla and six chocolate samples, ware bellow the $4.5 \mathrm{lb} / \mathrm{gal}$ legal limit and consequently, they were also judged to be high in overrun (higher than 100\%, which is the highest legal limit).

The average values of all tests were very close between vanilla and chocolate samples, with the latter being slightly higher in $\mathrm{pH}$ values.

Six vanilla $(18.7 \%)$ and eight (27.6\%) chocolate samples gave high microbial count readings for either total plate or/and coliform.

From the sensory evaluation tests that were run on the samples, the most frequent comments were on flavor, ("lacks freshness", "storage", "old ingredient", "lacks fine flavor" ). The next three comments in descending order were: melting, ( "does not melt"), body and texture, ("gummy", "soggy", "icy" ) and color, ( "insufficient color" ).

From the ranking of the samples, we can see that chocolate, having 4 blue and 8 red ribbons, received higher acceptance compared to vanilla which received 2 blue and 5 red ribbons.

The presentation of the results during the annual 
N.I.C.Y.R.A. convention was an enlightening experience. The ice cream clinic was very demanding physically as well as mentaly. On the day of the clinic, a short presentation of the work done was made by Professor $c$. Cosgrove. Following that, all samples, still coded, had to be set up on desplay tables along with their data sheets. All participants were given their own results and had the opportunity to examine the samples and comment on the results.

It was made clear, through conversations during the clinic, that industry people look at the product at a different prespective. Despite the somewhat different approach, common ground was easily found on the acievement of high quality ice cream.

overall, the investigator gained a broader knowledge on the subject of ice cream by dealing directly with members of the industry and participating in discussions concerning the latest trends in the market. 
ICE CREAY CLINIC AND BAMPLING

NICRA - 1989

Final Ranking of Vanilla samples.

Rank

Total points

code Number

BLUE

1

28.91

28.16

9340

2411

RED

27.75

26.58

26.45

26.36

26.27

6947

2134

9550

2125 C

8529

WHITE

8

9

10

11

12

13

14

15

16

17

18

19

20

21

22

23

24

25

26

27

28

29

30

31

32
25.90

25.80

25.41

24.58

24.50

23.91

23.83

23.50

23.25

23.00

23.00

23.00
2806

1570

6776

9500

6032

3026

1378

1949

7790

2125 b

4242

9700

\section{UNCLASSIFIED}

22.75

22.63

22.50

22.16

22.00

21.08

21.08

21.00

21.00

20.33

19.83

19.72

16.50

3952

9490

9600

9208

3301

9300

3245

1437

7858

1596 


\section{ICE CREAM CLINIC AND SAMPLING}

\section{NICRA - 1989}

Final Ranking of Chocolate samples.

Rank

Total Points

Code Number

BLOE

128.44

$\begin{array}{ll}2 & 28.30 \\ 3 & 28.00\end{array}$

$2125 c$

3026

28.00

6032

4

RED

27.70

27.62

27.60

27.33

26.90

26.54

26.50

9340

26.00

WHITE

$$
\begin{aligned}
& 25.59 \\
& 25.50 \\
& 23.38 \\
& 23.00
\end{aligned}
$$

1949

8529 b

3952

9700

2806

2134

1596

6776

\section{UNCLASSIFIED}

22.63

22.50

22.33

22.10

22.00

21.78

21.60

21.44

20.55

19.80

17.92

17.20

8529 a

3245

2125 b

7790

14.78

6947

9300

9490

1437

9208

9550

4242

9500

1570

2411

3301

9600

28
29

9392 


\section{ICE CREAY CLINIC AND SAKPLING \\ NICRA - 1989}

$\begin{array}{ll}\text { Total samples submitted: } & 32 \text { Vanilla } \\ & 29 \text { Chocolate }\end{array}$

Brand Names Participating: 30

SUMMARY OF PLACINGS:

Category

Range

Vanilla

Chocolate

Blue

Red

White

$30.00-28.00$

2

$26.00-27.99$

5

Unclassified

$23.00=25.99$

12

13

4

$<22.99$

13 
ICE CREAM CIINIC AND BAMPIING

\section{$\underline{\text { NICRA }-1989}$}

Bummary of Analyses for Vanilla samples.

\begin{tabular}{|c|c|c|c|c|c|c|c|c|}
\hline 된 & 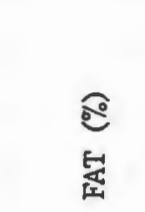 & $\begin{array}{l}\text { 㝵 } \\
\text { 总 } \\
\text { 녕 }\end{array}$ & 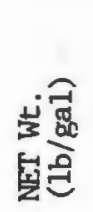 & 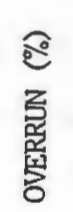 & 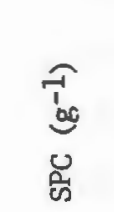 & 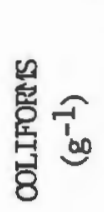 & 至 & 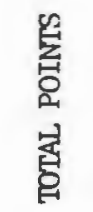 \\
\hline 1378 & 14.6 & 39.6 & 5.98 & 52 & 15000 & 5 & 5.85 & 23.83 \\
\hline 1437 & 14.8 & 39.1 & 4.37 & 108 & 550 & $<1$ & 6.15 & 21.00 \\
\hline 1570 & $17 \cdot 4$ & 43.5 & 4.84 & 88 & 1800 & $<1$ & 6.20 & 25.80 \\
\hline 1596 & 12.2 & 37.5 & 4.81 & 89 & 32000 & 180 & 6.45 & 20.33 \\
\hline 1949 & 17.0 & 41.1 & 4.66 & 95 & 76000 & 200 & 6.20 & 23.50 \\
\hline $2125 a$ & 12.8 & 38.5 & 6.06 & 50 & 48000 & 10 & 6.60 & 19.72 \\
\hline $2125 b$ & 12.5 & 40.0 & 6.02 & 51 & 29000 & $<1$ & 6.75 & 23.00 \\
\hline $2125 c$ & 11.0 & 41.0 & 5.05 & 80 & 17000 & $<1$ & 6.65 & 26.36 \\
\hline 2134 & 14.8 & 39.2 & 5.76 & 58 & 1400 & $<1$ & 6.45 & 26.58 \\
\hline 2411 & 12.4 & 39.9 & 5.87 & 55 & 2100 & 10 & 6.10 & 28.16 \\
\hline 2806 & 11.4 & 37.0 & 4.86 & 87 & 800 & $<1$ & 6.55 & 25.90 \\
\hline 3026 & 12.4 & 38.6 & 4.55 & 100 & 38000 & 5 & 6.50 & 23.91 \\
\hline 3245 & 18.3 & 10.9 & 4.37 & 108 & 200 & $<1$ & 6.80 & 21.08 \\
\hline
\end{tabular}




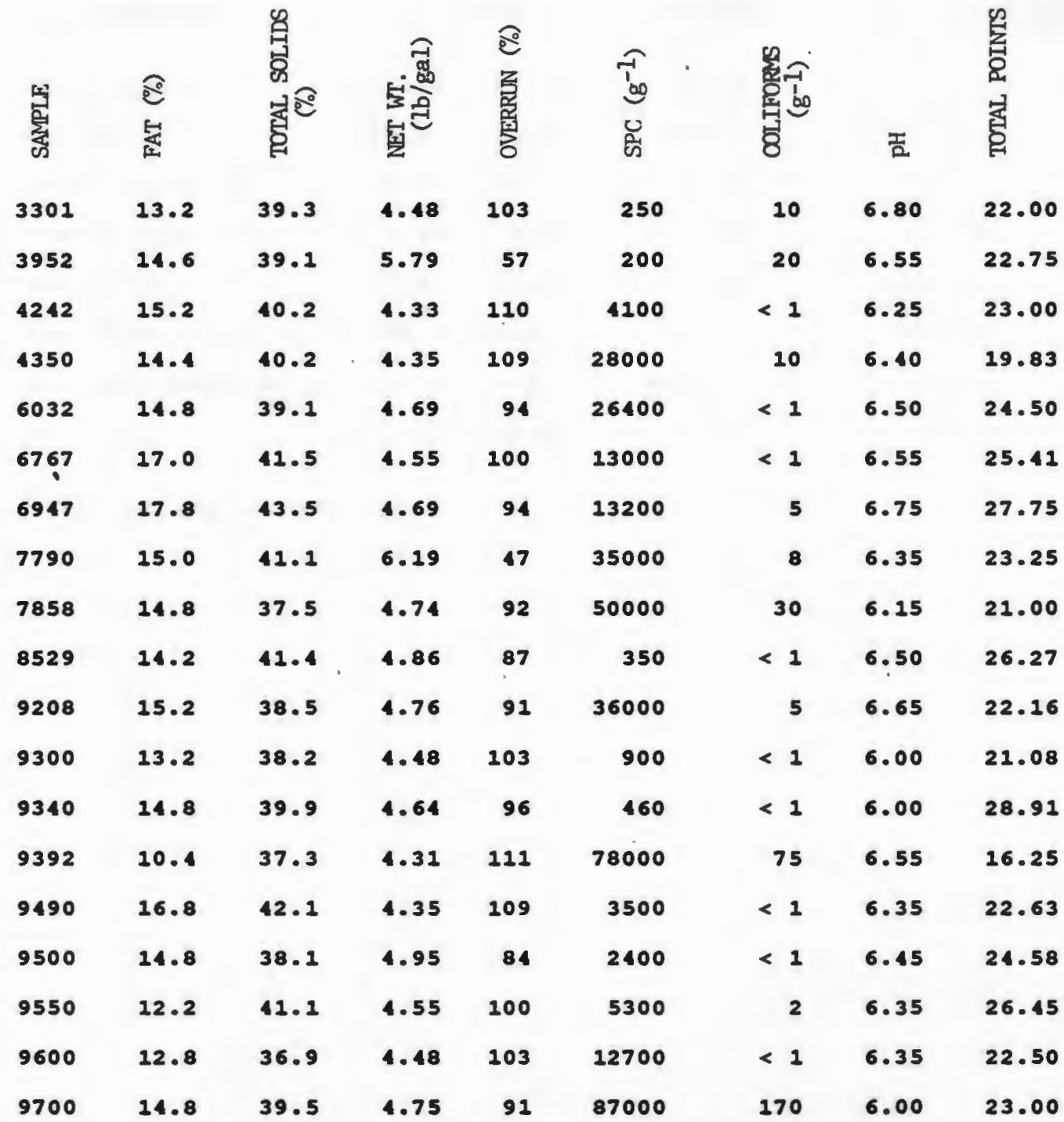


characteristic

Total Points

rat (r)

Total solids (\%)

Weight / gal (1b)

overrun (\%)

8td. Plate count $\left(g^{-1}\right.$

coliform count $\left(\mathrm{g}^{-1}\right)$

PH

Range

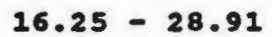

$18.3-10.4$

$43.5-36.9$

$6.19-4.31$

$47.0-111.0$

$200-87000$

$<1-200$

$5.85-6.80$

Total Vanilia samples : 32
Average

$23 \cdot 52$

2.77

14.28

39.69

4.91

87.56

20.35

1.99

1.72

0.594

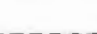




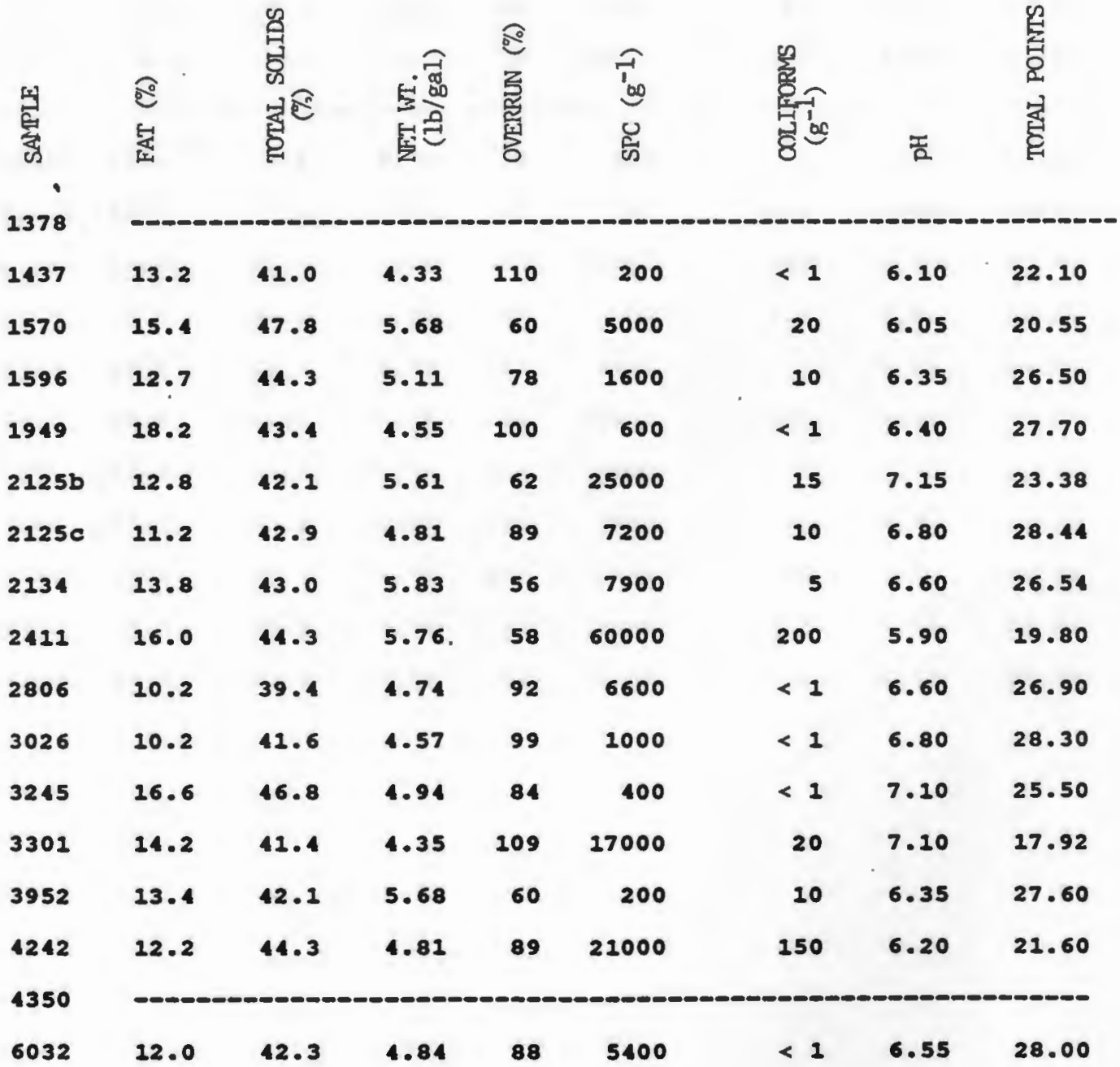




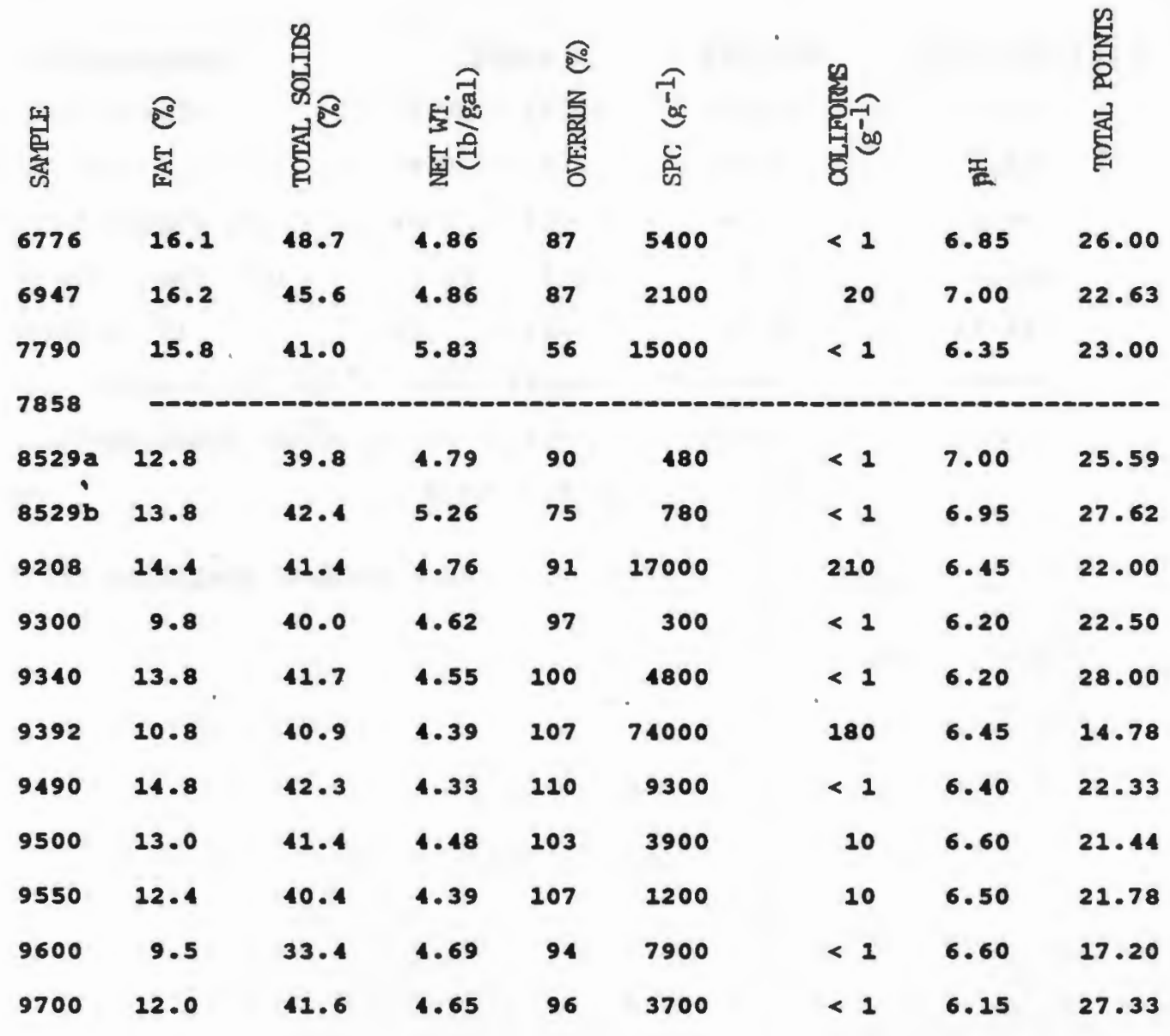




\begin{tabular}{|c|c|c|c|}
\hline Characteristic & Range & Average & std. Deviation \\
\hline Total Points & $14.78-28.41$ & 23.83 & 3.74 \\
\hline Fat $(r)$ & $9.5-18.2$ & 13.3 & 2.22 \\
\hline Total solids (r) & $48.7-33.4$ & 42.4 & 2.86 \\
\hline Welght / gal (1b) & $4.33-5.83$ & 4.90 & 0.486 \\
\hline Overrun (z) & -110 & 87.30 & 17.42 \\
\hline $\begin{array}{l}\text { std. Plate count }\left(g^{-1}\right) \\
\text { coliform count }\left(g^{-1}\right)\end{array}$ & $\begin{array}{l}200-74000 \\
<1-210\end{array}$ & $-\cdots--$ & $---\infty$ \\
\hline pH & $5.90-7.15$ & & \\
\hline
\end{tabular}




\section{BIBLIOGRAPHY}

A.O.A.C. 1980a. Nitrogen: Macro Kjeldal Method. In: "Oficial Methods of Analysis of the oficial Analytical Chemists". 13th ed. w. Horwitz (Ed.). Washington, DC.

A.O.A.C. 1980b. Total Solids for Dairy Products. In: "Official Methods of Analysis of the official Analytical Chemists". 13th ed. W.Horwitz (Ed.). Washington, DC.

Allingham R.P. 1982. "Polydextrose - A new food ingredient. Technical aspects". Pfizer, Groton, Connecticut.

Anonymous. 1984. "Polydextrose. Development and FDA Approval". Food Processing. 45(4):29-30. Anonymous. 1988. "FDA clears Hoechst's non-caloric sweetner for use in dry foods". Food Technol.42(10):108

Arbuckle W.S. 1986. "Ice cream." 4th ed. Avi Publishing Co., Westport, CT.

Arky R.A. 1984. Prevention and therapy of diabetes mellitus. In "Present knowledge in nutrition". 5th ed. The Nutrition Foundation, Washington, DC. Beckman Industries, 1982. Instruction Manual. Models HIC-1 \& HIC-2. Beckman Industries, Inc., Cedar Grove, NJ. 
Beereboom J.J. 1979. Low calorie bulking agents. In:

"Reviews in Food Science and Nutrition". R.C.C. p.401-413, May.

Bowen W.H. 1984. Role of sugars and other. sweeteners in dental caries. In: "Aspertame: physiology and biochemistry". Marcel Dekker, New York, N.Y. Bowers A.and Church H.N. 1985. "Food Values of Portions Commonly Used". 14th ed. J.B. Lippincoff Co., Philadelphia.

Caliendo M.A. 1987. "Nutrition and preventive health care". Macmillan Press. NY.

Charley H. 1982. "Food Science". 2nd ed. John Wiley \& Sons, NY.

Code of Federal Regulations. 1982. Federal Food, Drug and Cosmetic Act, Part 20, Title 21. F.D.A. Washington, DC. Consumer Reports. 1989 "Ice cream bars for big kids".

Consumer Reports. August.

Crede B. 1985. "Why lactaid: the problem with milk and answers". Lactaid Co., Pleasantville, NJ .

Dahlqvist A. 1984. Carbohydrates. In: "Present knowledge in nutrition". 5th ed. The Nutrition Foundation, Washington, D.C.

Dartey C.K., Biggs R.H. and Patterson. 1987. Reduced calorie baked goods and methods for producing same. U.S. patent $4,668,519$, May 26 . 
Dairy Situation and Outlook Report. Oct. 1987. USDA

Economic Research Service. DS-412, Washington, DC. DeAngelis, M.A. 1979. The development and use of a lactase capsule to alleviate the characteristic symptoms of lactose intolerance. M.S. Thesis, University of Rhode Island, Kingston, R.I.

Dermot O'Sallivan. 1983. "New sweetners gain ground in

Europe". Chem. \& Engin. News, January 24.

Dzieza J.D., 1988e. "Emulsifiers: The interfacial key to emulsion stability". Food Technol.42(10):172-186

Elliott R.,1988. "Trends in Industry". Dairy Field. $171: 12,10-12$

FDA, 1988. "Approval of Acesulfame K". Federal Register Vol. 53, p. 28379-28383.

Fennema O.R. 1985. "Food Chemistry". 2nd ed. Marcel

Dekker, New York, N.Y.

Finer N. 1988. Consequences of obesity. Ch.14. In: "Low calorie products". Brich G.G. and Lindley M.G. (Ed)., p.199. Elsevier Applied Science, New York, N.Y. Freeman T.M. 1982. "Polydextrose for reduced calorie foods". Cereal Foods World, Vol.27(10):515-518. Hendley B.G. and Seymour V. 1988. Markets for Low Calorie Foods. Ch.1. In: "Low calorie products". Brich G.G. and Lindley M.G. (Ed.), p.1. Elsevier Applied Science, New York, N.Y. 
Hoechst, 1988d. "Sunette - the sure way to solve the sweetening problem". Hoechst, NY.

Houts S.S. 1988. "Lactose Intolerance". Food Technol. $42(3): 110-113$.

I.I.C.A., 1988. The Latest Scoop. International Ice Cream Association. Washington, DC.

Klis B.J., 1986. "Sweetners". Food Technol. 40(1):112-130. Leeder J.G. 1981. "Ice cream short cources manual". Cook College, Rutgers, NY.

Lehninger A.L. 1982. "Principles of Biochemistry". Worth Publishers, Inc., New York, N.Y.

Lipinski, Gert-Wolfhard von Rymon. 1985. "The new intense sweetener Acesulfame-K". Food Chem. 16(3):259.

Lipinski G.-W. 1988. Acesulfame-K: Properties, Physiology and Applications in Calorie-Reduced and Low-Calorie Products. Ch.8. In "Low-calorie products". Bich G.C. and Lindley M.G. (Ed), p.101-112. Elsevier Applied Science, New York, N.Y.

M.I.F., 1959. "Laboratory Manual. Methods of Analysis of Milk and its Products". Milk Industry Foundation. Washington, DC.

Martini M.C., Smith D.E. and Savaino D.A. 1987. "Lactose digestion from flavored and frozen yogurts, ice milk and ice cream by lactase-deficient persons". Am.J.Clin.Nutr. 46:636-40. 
Medallion Laboratories. 1986a. "Non-nutritive sweetners: A rocky road to sweetness". Medallion Lab. Analytical Progress. Vol.3, No.1, Feb.

Mermelstein N.H. 1989. "Low-Calorie Foods". Food Technology, $43(4): 113-125$. Metcalfe J.A. 1988. The Importance of Energy-Reduced Diets in the Managment of Diabetes. Ch.15. In: "Low calorie products". Brigh G.G. and Lindley M.G. (Ed), p.215-222, Elsevier Applied Science, New York, N.Y. Microlife Inc., 1989b. "Sherex 302. Product Information". Microlife-mpi, Inc., Sarasota, FL. Murphy S. 1986. Sugar free low lactose ice cream. M.S. thesis, University of Rhode Island, Kingston. Murray P.R. 1988. Polydextrose. Ch.7. In "Low-calorie products". Birch G.C. and Lindley M.G. (Ed), p.83-99. Elsevier Applied Science, New York, N.Y. N.I.H., 1987. "Consumers development statement on health implications of obesity". Vol.5, No 9, National Institute of Health, Bethesda, MD.

Nielsen B.J. 1984. "Combined emulsifier/stabilisers for ice cream". Ice Cream and Frozen confectionery, $35(20): 401-410$.

Pfizer Inc,1985. "Pfizer polydextrose for the market that is shaping up". Pfizer Inc., Chemical Division, NY. 
Post F.J. 1983. "Laboratory Manual for Food Microbiology". Star Publishing Co., Belmont, CA. Potter N.N. 1978. "Food Science" 3rd ed. Avi Publishing Co., Westport, Connecticut. Scrimshaw N.S. and Murray E.B. 1988. "The Acceptability of Milk and Milk Products in Populations with a High Prevelance of Lactose Intolerance". Am. J. Clin. Nutrition, $48(4): 1083-1147$.

Skinner S. and Martems R. 1987. "The milk sugar dilema: living with lactose intolerance". Medi-ed Press, East Lancing, MI.

Smiles R.E. 1982. "The functional applications of Polydextrose". Pfizer Inc., Groton, Connecticut. Sommer H.H. 1951. "The Theory and Practice of Ice Cream Making". 6th ed. Sommer Hugo, Madison, Wisconsin. The Surgeon General's Report on Nutrition and Health. 1988. U.S. Department of Health Service. Publ. No. 88-50210, Washington, DC. Torces A. and Thomas R.D. 1981. "Polydextrose and its applications in foods". Food Technol. Vol.35:44-49. Torres A. 1986. Preparation and use of a highly purified polydextrose. U.S. patent 4.622 .233 , Nov 11 . Walstra P. and Jenness R. 1984. "Dairy chemistry and physics". John wiley and Sons. New York, N.Y. 
Wittinger S.A. and Smith D.E. 1986. "Effect of Sweeteners and stabilizers on Selected Sensory Attributes and Self Life of Ice Cream". J. of Food Science $51(6): 1463-1466$. 